Int. J. Dev. Biol. 54: 377-390 (2010)

doi: $10.1387 / \mathrm{ijdb} .082765 \mathrm{md}$

\title{
Placental nutrient supply and fetal growth
}

\author{
MICHELLE DESFORGES* and COLIN P. SIBLEY \\ Maternal and Fetal Health Research Group, School of Clinical and Laboratory Sciences, \\ University of Manchester, St Mary's Hospital, Manchester, UK
}

\begin{abstract}
This review considers mechanisms by which transfer across the placenta takes place and how the capacity of the placenta to supply nutrients relates to fetal growth and vice versa. Blood flow through both uterine and umbilical circulations of the placenta, the structural properties of the placental exchange barrier and its related diffusional permeability, and the expression and activity of a wide range of transporter proteins in the syncytiotrophoblast, the transporting epithelium of the placenta, all need to be taken into account in considering placental supply capacity. We discuss the evidence that each of these factors affects, and is affected by, fetal growth rate and consider the regulatory mechanisms involved, with a particular focus on data that has emerged from study of the system $A$ amino acid transporter. We consider that future work will build on the considerable foundation of knowledge regarding placental transfer mechanisms, as well as the other aspects of placental structure and function, to develop new diagnostic and therapeutic strategies for pregnancy complications, such as fetal growth restriction or overgrowth.
\end{abstract}

KEY WORDS: placenta, fetus, syncytiotrophoblast, system A

\section{Introduction}

The placenta is responsible for the transfer of the bulk of substances between maternal and fetal circulations including oxygen, carbon dioxide, water, and all the necessary nutrients required by the fetus. Consequently, fetal growth is intimately linked to the exchange functions of the placenta and the size of a fetus at birth directly reflects the net transfer of solutes and water across the placenta over the course of gestation. What has interested our research group over nearly three decades of placental research, is the extent to which placental transfer mechanisms regulate fetal growth and vice versa. This review considers some of the issues that have arisen from this theme: we compare the mechanisms of maternofetal exchange across the placenta in normal pregnancy and describe how these are altered in relation to fetal growth restriction (FGR) and fetal overgrowth.

\section{The placental exchange barrier and exchange path- ways}

Any substance that passes between the maternal and the fetal circulation is faced with a number of anatomical barriers. The actual number and nature of these vary markedly between species (Atkinson et al., 2006). In the human, the first step involved in crossing the placenta requires transport across the microvillous plasma membrane (MVM) of the syncytiotrophoblast, the transporting epithelium of the placenta (Fig. 1). Once in the cytoplasm, molecules destined for the fetus exit from the syncytiotrophoblast via the fetal facing basal plasma membrane (BM). The MVM and the $\mathrm{BM}$ are probably the most important membrane barriers involved in maternal-fetal transfer (Sideri et al., 1983). They represent the limiting step in transport of the primary fetal nutrients such as glucose and amino acids. As in other epithelial cells, the differences in the type, number, and activity of transporters in these two plasma membranes provide the basis for vectorial transport towards the fetus (Eaton and Yudilevich, 1981; Smith et al., 1992). Net transport towards the fetus will result if the influx is greater than efflux across MVM and efflux is greater than influx across BM. Molecules then have to pass through the villous

\footnotetext{
Abbreviations used in this paper: $\mathrm{BM}$, basal membrane; BMI, body mass index; $\mathrm{E}_{\mathrm{m}}$, membrane potential; FGR, fetal growth restriction; GDM, gestational diabetes mellitus; $\mathrm{J}_{\mathrm{fm}}$, fetal to maternal unidirectional transfer rate; $\mathrm{J}_{\mathrm{mf}}$, maternal to fetal unidirectional transfer rate; LGA, large for gestational age; MeAIB, $\alpha$-(methylamino) isobutyric acid; MVM, microvillous membrane; NHE, $\mathrm{Na}^{+} / \mathrm{H}^{+}$exchanger; PMCA, plasma membrane calcium ATPase; PTHrP, parathyroid hormone related peptide; SNAT, sodium coupled neutral amino acid transporter.
}

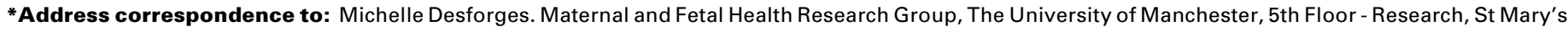
Hospital, Oxford Road, Manchester, M13 9WL, UK. Tel: +44-161-7016986. Fax: +44-161-701-6971. e-mail: michelle.desforges@manchester.ac.uk Web: http://www.medicine.manchester.ac.uk/maternalfetal/
} 
stroma and cross the fetal capillary endothelium before entering the fetal circulation (Fig. 1). The fetal capillary endothelium is of the continuous type and allows unrestricted passage of small solutes within the interendothelial clefts but diffusion of small peptides and larger sized molecules through these clefts will be restricted to an extent related to their molecular radius (Brownbill et al., 1995; Eaton et al., 1993; Firth et al., 1983; Leach and Firth, 1992; Michel and Neal, 1999; Sibley et al., 1982). The issues of solute permeability will be discussed further below.

Placental transfer has been the focus of many reviews which document the various transport pathways in detail (Atkinson etal., 2006; Boyd et al., 1994; Morriss et al., 1994; Sibley and Boyd, 2004; Smith et al., 1992). These pathways include those mediated by diffusion and those utilizing transcellular mechanisms, mediated by transporter proteins in the plasma membranes, as discussed in the following sections.

\section{Diffusion, blood flow and permeability}

\section{Diffusion}

Most exchange across the placenta is driven by diffusion or modifications of this process. A maternofetal concentration difference of any molecule, or electrochemical gradient for charged molecules, will lead to diffusion of that molecule across the placenta down its concentration gradient. There are, broadly, two pathways available for diffusion; a lipophilic route (for lipid-soluble molecules), and a hydrophilic route (for lipid-insoluble molecules). The net rate of diffusional transfer (flux) $\left(\mathrm{J}_{\text {net }}\right)$, according to Fick's law for a particular solute, depends on the surface area available for diffusion per gram of placenta (S), the diffusion coefficient in water at $37^{\circ} \mathrm{C}\left(D_{w}\right)$ of that solute (directly proportional to molecular size), the path length over which diffusion takes place (I), or membrane thickness, and the maternofetal concentration difference of that substance $\left(c_{m}-c_{f}\right)$ i.e. $J_{\text {net }}=S D_{w} /\left(C_{m}-C_{f}\right) \mathrm{mol} / \mathrm{sec} /$ $g$ placenta. For any mechanism of transfer within the placenta, $J_{n e t}$ can be considered as having two components: $J_{\text {net }}=J_{m f}-J_{f m}$. Here, $J_{m f}$ and $J_{f m}$ refer to unidirectional transfer rates in the maternofetal and fetomaternal directions respectively (Sibley and Boyd, 2004). Fetal growth requires that $J_{m f}$ for metabolic and synthetic substrates and water exceeds $\mathrm{J}_{\mathrm{fm}}$ over the course of pregnancy and therefore these variables control fetal growth by influencing either unidirectional flux. $\mathrm{J}_{\mathrm{mf}}$ and $\mathrm{J}_{\mathrm{fm}}$ are defined above in terms of diffusional exchange but the total flux in each direction will be via diffusion plus that via all the other available transfer mechanisms as considered below.

\section{Blood flow}

Lipophilic substances such as the respiratory gases dissolve readily through the entire syncytiotrophoblast plasma membrane (Fig. 2A). Because of the large surface area available to this process, such diffusion is said to be flow limited: net transfer will depend on the maternofetal concentration difference of the gas, which itself depends on the flow rates of the uterine and umbilical circulation. It is therefore unsurprising, mechanistically, that abnormalities in blood flow through both vascular beds are associated with FGR (Cnossen et al., 2008; Karsdorp et al., 1994). Indeed, in uterocord blood sampling has demonstrated that FGR is associated with hypoxemia (Pardi et al., 1993).

Failure of normal trophoblast invasion into the decidua in early

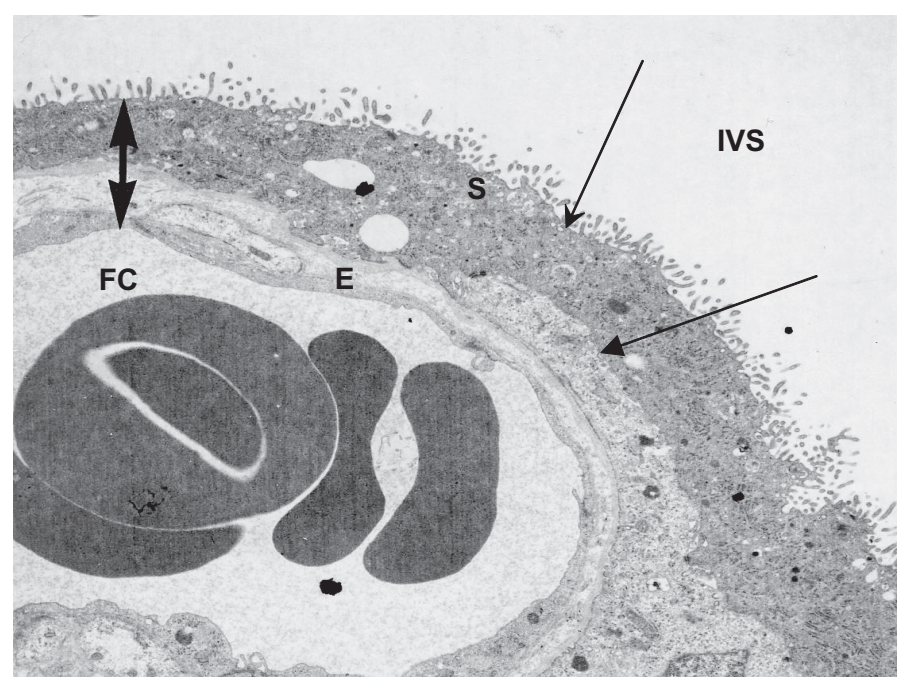

Fig. 1. Electron micrograph image (courtesy of C.J.P. Jones) of the placental exchange barrier. IVS is the intervillous space containing maternal blood; FC is the fetal capillary containing fetal blood; $S$ is the syncytiotrophoblast; $E$ is the fetal capillary endothelium. Single headed arrows point out the microvillous (maternal facing) and basal (fetal facing) plasma membranes of the syncytiotrophoblast. Double headed arrow demonstrates the entire barrier, at one point, across which transfer between maternal and fetal blood must take place.

pregnancy may lead to the failure of the normal transformation of the spiral arteries supplying blood directly into the intervillous space on the maternal side of the placenta (Fig. 1) (Aplin, 1991; Pijnenborg et al., 1983). This will lead directly to the poor uterine artery blood flow, as detected by ultrasound Doppler velocimetry measurements, in FGR (Cnossen et al., 2008; Karsdorp et al., 1994). This failed invasion and transformation may also be the root cause of abnormal placental development in FGR as well as other pregnancy complications such as pre-eclampsia (Aplin, 1991; Pijnenborg et al., 1983). One effect of this abnormal placental development is malformation of the fetoplacental vascular bed of the umbilical circulation (Kingdom et al., 2000). Again this leads to high resistance and abnormal umbilical blood flow in FGR as assessed by ultrasound Doppler (Cnossen et al., 2008; Karsdorp et al., 1994).

Uterine and umbilical Doppler velocimetry is widely used in clinical practice to assess women at high risk of FGR and there is a wealth of literature on this subject (Botsis et al., 2006). There is therefore a tendency for abnormal placental blood flow to be considered the sole cause of poor nutrient supply and consequently of FGR. This is not the case. Abnormal patterns of uterine artery Doppler signal show poor sensitivity and specificity for adverse outcome (Aardema et al., 2001); this can be improved by combining Doppler with biochemical measurements of placental barrier function (Toal et al., 2008a). Furthermore, growth restricted fetuses have lower plasma concentrations of amino acids than infants of normal size (Cetin et al., 1990; Cetin et al., 1988; Cetin et al., 1992). The physicochemical characteristics of these hydrophilic nutrients dictate that they do not readily cross the placental plasma membrane, their rate of transfer is much slower than that of the gases, and is limited much more by the properties of the exchange barrier than by blood flow. Therefore, all aspects of the placental exchange pathways have to be considered in 
understanding FGR, and other fetal growth anomalies.

In addition to the structural changes mediating altered blood flow, there are a range of endocrine, paracrine and autocrine factors which are known to alter resistance in the placental circulation (Brownbill et al., 2003; Brownbill et al., 2007; Carter and Myatt, 1995). These are likely to be particularly important in feedback between fetal growth and uterine and umbilical blood flow because of the absence of any innervation of the placenta. However, there is virtually no information yet available on such feedback, other than evidence that vascular reactivity in chorionic plate arteries and veins from placentas of FGR pregnancies is altered, and that the former is unrelated to changes in ultrasound Doppler indices of the umbilical circulation (Mills et al., 2005; Wareing et al., 2006). This is an important area for future research with the potential for therapeutic modulation of the fetoplacental vessel reactivity using drugs primarily being developed for use in other vascular beds.

\section{Diffusional permeability of the placenta to hydrophilic mol- ecules}

Hydrophilic molecules have poor solubility in lipid bilayers and therefore do not easily cross plasma membranes (Dobson and Kell, 2008). Consequently, with reference to the Fick equation described above, the diffusional transfer of these substances is much less affected by concentration gradients (and therefore by blood flow unless this is very low) and is more affected by the surface area of the barrier available for diffusion and the thickness of this barrier. The S.Dw/I term in the Fick equation is conveniently described and measured as a permeability $x$ surface area product (P.S) in studies of diffusional permability of the placenta to hydrophilic molecules (Atkinson et al., 2006; Sibley and Boyd, 1988). P.S has been measured in vitro and in vivo in a number of different species (Atkinson et al., 2006; Sibley and Boyd, 1988) and two important facts have emerged. Firstly, P.S is inversely proportional to the radius of inert hydrophilic solutes of increasing molecular size. Secondly, such P.S values are much lower in the epitheliochorial placenta of e.g. sheep, than the haemochorial placenta of humans, rats, guinea pigs and mice (Atkinson et al., 2006; Sibley and Boyd, 1988) i.e. the latter species have a much higher permeability.

The fact that P.S for inert hydrophilic solutes is inversely related to molecular radius, and therefore directly related to $D_{w}$, suggests that diffusion of these molecules must take place through extracellular water filled pores, bypassing the plasma membrane (Stulc, 1989). The morphological nature of these pores - sometimes referred to as a paracellular route (Fig. 2B) in haemochorial placentas is unclear but two possibilities appear to exist. The pores may be transtrophoblastic channels, which have been visualised in both the guinea pig and human placenta (Kaufmann et al., 1982; Kertschanska et al., 1994). Alternatively, a paracellular pathway may be provided during denudation of the syncytiotrophoblast (Brownbill et al., 1995; Brownbill et al., 2000; Edwards et al., 1993). This is a normal feature of the human placenta at all stages of gestation and the denudations are either open or filled with fibrinoid deposits (Nelson et al., 1990).

Whether P.S of the human is altered in relation to fetal growth has not been studied. There is stereological evidence that villous surface area of the human placenta in FGR is decreased and that mean barrier thickness is increased (Mayhew etal., 2007; Mayhew et al., 2003; Teasdale and Jean-Jacques, 1988), providing evidence that P.S might be decreased and contribute to the lower nutrient supply capacity of these placentas. Supporting evidence for this comes from mice where the placental-specific transcript of the insulin-like growth factor 2 (Igf2) gene was knocked out (Sibley et al., 2004). Fetuses of these mice are growth restricted by about $30 \%$ at term and this is associated with reduced P.S for inert hydrophilic solutes, decreased placental surface area and increased barrier thickness. This effect of $1 \mathrm{gf2}$ knockout also suggests that structural development of the placental barrier to diffusion might be hormonally modulated, perhaps enabling adjustment over the course of gestation in relation to changes in fetal growth rates.

Paracellular transfer of hydrophilic molecules across the placenta via extracellular pores may be quantitatively important for the exchange of small hydrophilic solutes such as calcium and chloride ions (Doughty et al., 1996; Stulc et al., 1994). The net diffusional flux of ions through the paracellular route will be determined by the electrochemical gradient across the syncytiotrophoblast. Transcellular routes of transfer across the placenta via specific transporters in the syncytiotrophoblast plasma membranes may be qualitatively of greater importance and allow fine tuning of net flux towards the fetus through cellular signaling events.

\section{Transcellular transport and membrane transporters}

Transporter proteins found in the plasma membrane responsible for the transport of hydrophilic molecules include channels and carriers. Channels are integral membrane proteins which transport ions down their electrochemical gradient (Fig. 2G). Although diffusion through channels is passive, it is also selective, gated and saturable. Carriers are integral membrane proteins which selectively combine with the solute and translocate it from one side of the plasma membrane to the other. This mechanism is saturable and may use energy from the prevailing electrochemical gradient (i.e. facilitated diffusion, Fig. 2C), or from the hydrolysis of ATP (i.e. active transport, Fig. 2F). Some carriers can transport more than one solute at a time, e.g. co-transporters which carry both solutes in the same direction (Fig. 2D), and exchangers which carry solutes in opposite directions (Fig. 2E). Carriers can harness the gradients generated by pumps by linking solute movements with, for example, $\mathrm{Na}^{+}$. Solutes are moved against their concentration gradient using this process of secondary active transport (Fig. 2D). Endocytosis, another form of transcellular transport, involves invagination of the plasma membrane to form an intracellular membrane-bound vesicle which contains extracellular fluid. The contents of the vesicle are released on the other side of the cell by a process called exocytosis (Fig. 2H): reviewed by Atkinson et al., 2006 (Atkinson etal., 2006). In the following sections we consider some placental transporter processes key for fetal growth and nutrition.

\section{Ion Transport}

Ion transport in the placenta subserves two functions, maintenance of cellular homeostasis in terms of electrochemical gradients and volume of placental cells, particularly important for the syncytiotrophoblast with its high rates of transcellular solute fluxes, and provision of cations and anions to the fetus. Several 


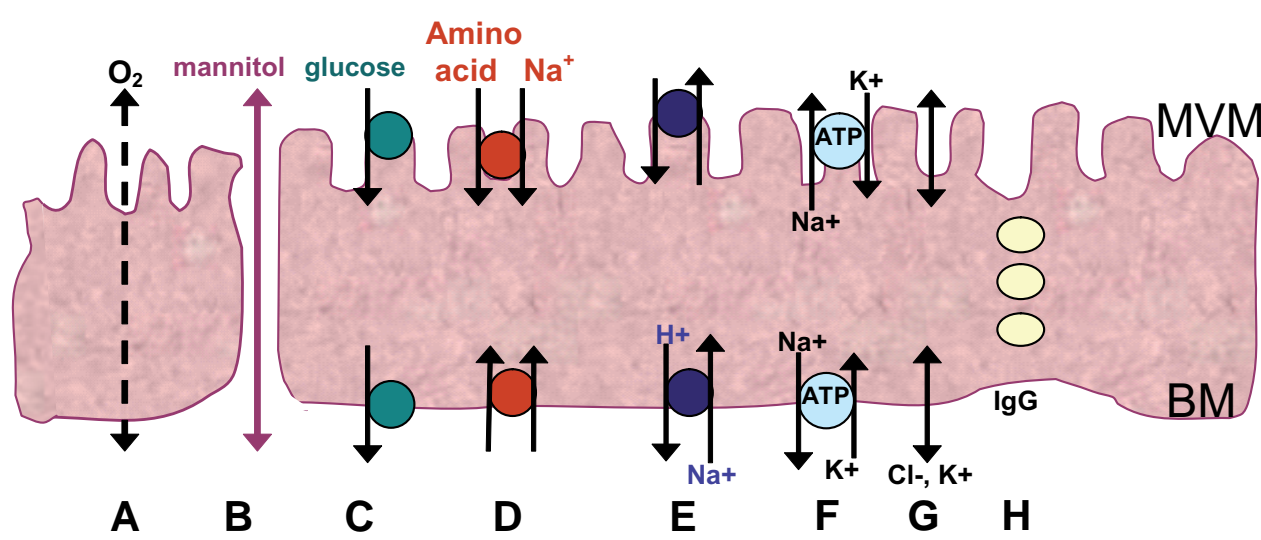

Fig. 2. Schematic diagram depicting the major mechanisms of transfer across the microvillous membrane (MVM) and basal membrane (BM) of the syncytiotrophoblast. (A) Simple diffusion of relatively lipophilic substances; transporter-mediated transport including (C) facilitated diffusion; (D) co-transport; (E) exchange; and (F) active transport. Ion channels (G) are present in the MVM and BM, and there is also evidence for endocytosis-exocytosis (H). Examples of the solutes transported by each mechanism are also given. (B) The paracellular route for the transport of hydrophilic substances is also indicated. ion transporters and conductances have been identified in the MVM and BM of the syncytiotrophoblast. A broad review of transport mechanisms for different cations and anions can be found in Atkinson et al., 2006. Here we focus on $\mathrm{K}^{+}, \mathrm{Na}^{+}$and $\mathrm{Ca}^{2+}$.

\section{Potassium channels}

As in all epithelia, the transmembrane ion concentration difference and the electrical potential difference (the electrochemical gradient) are important determinants of the rate and direction of transport of ions and of processes which involve the net transfer of charge (e.g. $\mathrm{Na}^{+}$-linked co-transport). With the use of microelectrodes, a fetal-side negative potential difference has been shown to exist across the human syncytiotrophoblast/cytotrophoblast layer (Greenwood et al., 1993a; Greenwood et al., 1996). The microvillous membrane potential $\left(E_{m}\right)$ is significantly more negative (hyperpolarized) in first trimester villi compared to term (Birdsey et al., 1997). In most cells $\mathrm{E}_{\mathrm{m}}$ depends primarily on the $\mathrm{K}^{+}$conductance of the membrane with other conductances and electrogenic transporters making little or no contribution. A difference in the relative $\mathrm{K}^{+}$conductance of the MVM between first trimester and term is most likely to contribute to the difference in the magnitude of the $E_{m}$ observed at these two gestations (Birdsey et al., 1997). Some progress has been made in identifying the $\mathrm{K}^{+}$ channels in the syncytiotrophoblast and these include Kir2.1 (Clarson et al., 2002; Mylona et al., 1998), TASK and TREK family members (Bai etal., 2005; Bai et al., 2006). There are $\mathrm{K}^{+}$channels present in the MVM (Fig. 2G) (Bai et al., 2005; Greenwood et al., 1993b) and, although an early study by Dancis et al.,1983 suggests the bulk of maternofetal $\mathrm{K}^{+}$transfer is by paracellular diffusion (Dancis et al., 1983), the regulation of $\mathrm{K}^{+}$channel activity is likely to be important for determining $E_{m}$, and thereby the cellular transport of charged solutes, cellular homeostasis and regulation of secretory processes. As regards cellular homeostasis, Birdsey et al., (1999) showed that hypoosmotic challenge of the syncytiotrophoblast resulted in activation of both $\mathrm{K}^{+}$, and anion, conductances (Birdsey et al., 1999) suggesting that they are involved in maintenance of cell volume. $\mathrm{K}^{+}$efflux is also stimulated by angiotensin and ATP, and there is evidence that the latter effects specifically the $\mathrm{Ca}^{2+}$ sensitive $\mathrm{K}^{+}$channels (Clarson et al., 2002; Siman et al., 2001). In relation to regulation of secretory processes, recent data show that specific $\mathrm{K}^{+}$channel blockers inhibit the secretion of human chorionic gonadotrophin from syncytiotrophoblast (Williams et al., 2007). These data suggest the importance of $\mathrm{K}^{+}$channels in syncytiotrophoblast function however there remains much still to be done in terms of identifying and characterising $\mathrm{K}^{+}$channels in the syncytiotrophoblast, delineating their function and determining how they are affected in fetal growth disorders.

\section{$\mathrm{Na}^{+} / \mathrm{K}^{+} / \mathrm{ATPase}$}

In some cells, a proportion of the $\mathrm{E}_{\mathrm{m}}$ is generated by the activity of the $\mathrm{Na}^{+} / \mathrm{K}^{+} /$ATPase or $\mathrm{Na}^{+}$pump (Fig. 2F). The $\mathrm{Na}^{+}$pump actively extrudes sodium from the cell in exchange for $\mathrm{K}^{+}$using energy in the form of ATP (Clarson et al., 1996). This generates an inwardly directed $\mathrm{Na}^{+}$gradient which in turn facilitates the $\mathrm{Na}^{+}$ entry mechanisms. In the placenta, this transporter was originally thought to be located predominantly on the BM (Kelley et al., 1983) as in other epithelia but, a more recent, thorough study showed that both expression and activity of $\mathrm{Na}^{+} / \mathrm{K}^{+} / \mathrm{ATP}$ ase is present on the MVM at levels twice that of the BM (Johansson et al., 2000). $\mathrm{Na}^{+} / \mathrm{K}^{+} /$ATPase activity is relatively low in the placenta compared to other transporting epithelia (Birdsey et al., 1997) and it does not contribute significantly to $E_{m}$ in cytotrophoblast cells (Greenwood et al., 1996) or intact syncytiotrophoblast (Birdsey et al., 1997). It is, however, involved in maintenance of high intracellular $\mathrm{K}^{+}$and low intracellular $\mathrm{Na}^{+}$concentrations (Greenwood et al., 1996) which are important driving forces for other transport systems discussed later in this chapter.

\section{$\mathrm{Na}^{+} / \mathrm{H}^{+}$exchanger}

There are various mechanisms for $\mathrm{Na}^{+}$transport into the syncytiotrophoblast including sodium conductances, $\mathrm{Na}^{+} / \mathrm{H}^{+}$exchange, and co-transport with inorganic ions and organic solutes (Shennan and Boyd, 1987). Entry of $\mathrm{Na}^{+}$into the cell via the conductive pathway involves movement of $\mathrm{Na}^{+}$down its electrochemical gradient (Chipperfield et al., 1988) but the nature of this pathway has not yet been characterised in syncytiotrophoblast. The $\mathrm{Na}^{+} / \mathrm{H}^{+}$exchanger (NHE) catalyses an electroneutral coupling of $\mathrm{Na}^{+}$influx into the syncytiotrophoblast with $\mathrm{H}^{+}$efflux (Balkovetz et al., 1986; Sibley et al., 2002) shown in Fig. 2E. The main function of the $\mathrm{NHE}$ is thought to be regulation of intracellular pH (Powell and Illsley, 1996). Co-transport with other molecules contributes significantly to the entry of $\mathrm{Na}^{+}$into the syncytiotrophoblast because a number of transport systems, including amino acid transporters, utilise the transmembrane $\mathrm{Na}^{+}$gradient as a driving force (Fig. 2D).

$\mathrm{Na}^{+} / \mathrm{K}^{+} /$ATPase, $\mathrm{NHE}$ and $\mathrm{Na}^{+}$channels might all be involved in syncytiotrophoblast homeostasis as well as in transport of the 
cation to the fetus. In the rat it has been possible, based on experimental data, to construct a model mechanism of transcellular $\mathrm{Na}^{+}$transport to the fetus, involving entry into the trophoblast across the maternal facing plasma membrane via $\mathrm{NHE}$ and $\mathrm{Na}^{+}$ co-transport with amino acids and other solutes, followed by extrusion on the fetal side via Na+/K+/ATPase (Sibley, 1994; Stulc etal., 1993). It is not clear how relevant this model is to the human, both because of the localisation of $\mathrm{Na}^{+} / \mathrm{K}^{+} /$ATPase described above and because it is likely that the paracellular diffusional route is more important than it is in rat (Sibley, 1994). However, whether it is involved in fetal supply or syncytiotrophoblast homeostasis, there does appear to be a strong relationship between reduced fetal growth and placental $\mathrm{Na}^{+}$transport. Both $\mathrm{Na}^{+} / \mathrm{K}^{+} /$ ATPase and NHE activities are reduced in placentas from growth restricted fetuses (Johansson et al., 2002; Johansson et al., 2003; Mahendran etal., 1993), as are the activities of some $\mathrm{Na}^{+}$-coupled amino acid transporters (see below). These effects could well be interrelated, perhaps with alterations in the electrochemical gradient for $\mathrm{Na}^{+}$across the plasma membranes of the syncytiotrophoblast playing a key role in the dysfunction of the epithelium in FGR.

\section{$\mathrm{Ca}^{2+}$ transport}

Placental transfer of $\mathrm{Ca}^{2+}$ to the developing fetus is essential for bone mineralization and, if this is abnormal, it may increase the risk of developing osteoporosis later in life (Tobias and Cooper, 2004). Fetal accretion of $\mathrm{Ca}^{2+}$ increases exponentially over the last third of pregnancy, concomitant with the development of the fetal skeleton (Comar, 1956), suggesting that there is cross talk between the two processes. Data suggest that in the mouse and rat placenta, as in other epithelia, $\mathrm{Ca}^{2+}$ transport is likely to involve three main steps (Atkinson et al., 2006; Belkacemi et al., 2005): firstly, diffusion into the trophoblast from maternal plasma down an electrochemical gradient through epithelial $\mathrm{Ca}^{2+}$ channels of the transient receptor potential (TRP) gene family; secondly, transfer across the trophoblast cytoplasm bound to the calcium binding protein calbindin- $D_{9 K}$ (Glazier et al., 1992); and, thirdly, active extrusion into the fetal compartment via plasma membrane $\mathrm{Ca}^{2+}$ ATPase (PMCA) localized to the BM (Borke et al., 1989; Fisher et al., 1987). Over the last third of gestation, gene and protein expression for calbindin- $D_{9 K}$ increases markedly in both mouse and rat placenta (An et al., 2004; Glazier et al., 1992; Hamilton et al., 2000; Mathieu et al., 1989) and correlates with the increase in unidirectional maternofetal ${ }^{45} \mathrm{Ca}$ clearance measured over the same period (Glazier et al., 1992), suggesting that transcytosolic transfer on this protein and the dynamic equilibrium between bound and free $\mathrm{Ca}^{2+}$ in the syncytiotrophoblast might be the rate limiting step of transfer in these species. The situation may well be quite different in the human placenta where it has proved difficult to show the expression of calbindin- $\mathrm{D}_{9 \mathrm{~K}}$ (Belkacemi et al., 2004), or to determine if another protein is involved instead. Interestingly, the activity, but not expression, of PMCA in the BM of human placenta increases linearly over the last third of gestation (Strid and Powell, 2000). This suggests that there is a signaling mechanism linking activity of PMCA in placental BM, and therefore $\mathrm{Ca}^{2+}$ transfer, to fetal bone mineralization, which is also increasing rapidly in the third trimester. Further evidence of a link to fetal calcium demand is from data showing that PMCA activity in the BM is increased in pregnancies affected by both FGR and those with maternal insulin dependent diabetes mellitus (Strid et al., 2003), where fetal overgrowth can occur. Although FGR is associated with reduced bone mineralization, the increased PMCA activity may be a response to increased fetal demand in this condition (Strid et al., 2003).

There is good evidence that parathyroid hormone related peptide (PTHrP) is involved in controlling placental $\mathrm{Ca}^{2+}$ transfer. In fetal mice with the PTHrP gene knocked out, $\mathrm{Ca}^{2+}$ transfer across the placenta is altered, though there is disagreement between studies, which might have a methodological basis, as to whether knockout leads to decreased (Kovacs et al., 1996) or increased (Bond et al., 2008) $\mathrm{J}_{\mathrm{mf}}$ for $\mathrm{Ca}^{2+}$. Interestingly, Strid and colleagues have shown that PTHrP stimulates $\mathrm{Ca}^{2+}$ ATPase activity in human $\mathrm{BM}$ in vitro (Strid et al., 2002). Furthermore, umbilical cord plasma concentrations of PTHrP are increased in FGR, perhaps providing the stimulus for the increased PMCA activity in these pregnancies (Strid et al., 2003). Therefore, PTHrP might be a signal relating fetal $\mathrm{Ca}^{2+}$ demand to placental $\mathrm{Ca}^{2+}$ supply.

\section{Glucose transport}

Fetal growth and development is dependent on an adequate supply of nutrients from the mother, in particular glucose and amino acids. Glucose is a primary energy source for the fetus. Investigations using syncytiotrophoblast membrane vesicles and placental perfusion have shown that transport of glucose across the human placenta is saturable, stereo-specific, shows competition, and is independent of energy sources i.e. it shows all the characteristics of facilitated diffusion (Fig. 2C) (Bissonnette et al., 1981; Johnson and Smith, 1985; Rice et al., 1976). Glucose transport in mammalian tissues is mediated by the GLUT gene family of facilitated diffusion transporters of which there are at least twelve members (Joost and Thorens, 2001). The fetal plasma glucose concentration is lower than that in the maternal circulation even though one study estimated that the glucose transfer capacity of the MVM is many fold higher than would be required to supply fetal and placental needs (Johnson and Smith, 1980). It is likely the maternal-fetal glucose gradient may arise from limitation of overall transyncytial transfer by the lower transport capacity of the BM (Johnson and Smith, 1985). Interestingly, it has been shown clearly that neither MVM nor BM GLUT expression and activity is altered in pregnancies affected by FGR (Jansson et al., 1993; Jansson et al., 2002b). In fetal overgrowth, glucose transport across MVM is unaltered but there is some evidence of increased glucose transport across the BM (Gaither et al., 1999; Jansson et al., 2001; Jansson et al., 1999).

\section{Amino acid transport}

The identification and kinetic properties of different amino acid transport systems in placenta has been investigated extensively using membrane vesicles prepared from MVM and BM of the human syncytiotrophoblast (Hoeltzli and Smith, 1989; Kudo et al., 1987; Smith et al., 1974). Analysis of the different amino acid transporters found in the placenta has been challenging due to the large number of amino acid substrates, the overlapping specificity of the transporters, and 
the complicating factor of placental metabolism and utilisation of amino acids (Battaglia, 1986). Based on competitive interactions between amino acid substrates, at least 15 transport systems for neutral, basic and acidic amino acids have been identified in the placenta analogous to those described for other epithelia (Jansson, 2001; Moe, 1995). Many of the amino acid transporters have now been cloned and characterised at the molecular level (Kudo and Boyd, 2002). The genes encoding the different transporters are divided into different solute carrier (SLC) families. For example, the SLC38 family encodes the system $A$ and system $\mathrm{N}$ neutral amino acid transporters (Hediger et al., 2004).

In healthy fetuses, umbilical cord blood concentrations of most amino acids are significantly higher than maternal concentrations at mid gestation and term with the exception of aspartate and glutamate (Cetin et al., 1990; Mclntosh et al., 1984; Philipps et al., 1978; Soltesz et al., 1985). Placental tissue concentrations of free amino acids appear to be higher than in both fetal and maternal plasma (Camelo et al., 2004; Philipps et al., 1978). Energy is therefore required to transport amino acids into the syncytiotrophoblast against their concentration gradient. The most generally accepted classification of amino acid transporters divides them into two systems - those that co-transport $\mathrm{Na}^{+}$with the amino acid $\left(\mathrm{Na}^{+}\right.$-dependent systems), and those that do not ( $\mathrm{Na}^{+}$-independent systems) (Christensen, 1982). $\mathrm{Na}^{+}$-dependent amino acid transporters are secondary active transporters because they do not directly utilise ATP. Instead they harness the active energy of the $\mathrm{Na}^{+}$/ $\mathrm{K}^{+}$/ATPase which creates the $\mathrm{Na}^{+}$gradient. It is the energy stored in the $\mathrm{Na}^{+}$electrochemical gradient that is used to transport the amino acid substrates of the transporters against their concentration gradient (Sibley and Boyd, 1998). It is not immediately apparent what represents the driving force for the uphill transport of amino acids across MVM by $\mathrm{Na}^{+}$-independent transporters. System $L$ exhibits strong trans-stimulation i.e. uptake is stimulated by high intracellular concentrations of another neutral amino acid (Christensen, 1990; Jansson et al., 1998). Possible candidates for trans-stimulation of System $L$ activity are glycine and serine, which are transported by system $A$. System $y^{+} L$ is a $\mathrm{Na}^{+}$-independent cationic amino acid transporter that carries a net positive charge. It is therefore likely that it is the electrical potential difference that provides the driving force for transport of cationic amino acids against their concentration gradient across MVM by this transporter.

Exit of amino acids from the syncytiotrophoblast across the $\mathrm{BM}$ towards the fetus is less well understood, although $\mathrm{Na}^{+}$independent pathways are thought to play an important role. There is evidence that amino acid exchangers in the BM may function to take up amino acids required in lower quantities by the fetus in exchange for placental amino acids for which the fetus has a higher metabolic requirement (Cleal et al., 2007). The non-specific permeability of BM in vitro to neutral amino acids is not insignificant (Hoeltzli and Smith, 1989; Jansson et al., 1998; Kudo and Boyd, 1990). Therefore it is possible that non-mediated transport across BM may contribute to exit of neutral amino acids from the syncytiotrophoblast towards the fetus, down their own concentration gradient.

Because fetal amino acid requirements for both metabolic and synthetic purposes are likely to be important determinants of fetal growth, we hypothesized that placental transport of these substrates and fetal growth are interrelated. Work in our laboratory has focused particularly on placental amino acid transport via the system $A$ transporter and how this is altered in both FGR and fetal overgrowth.

\section{System A amino acid transporter}

\section{Transporter mechanisms and characteristics}

System A primarily transports non-essential neutral amino acids such as alanine, glutamine, glycine, methionine, proline, serine, and threonine. It is a ubiquitous transporter that actively transports small, zwitterionic, neutral amino acids with short unbranched side chains (Johnson and Smith, 1988). Substrates are co-transported with $\mathrm{Na}^{+}$against their concentration gradient using the $\mathrm{Na}^{+}$electrochemical potential gradient across the cell membrane as a driving force. The $\mathrm{Na}^{+}$:amino acid stoichiometry is 1:1 (Hatanaka etal., 2000; Sugawara et al., 2000a; Wang et al., 2000) and $\mathrm{Na}^{+}$binding has been shown to precede binding of amino acid before simultaneous transport takes place (Mackenzie et al., 2003; Yao et al., 2000). This transporter is pH sensitive, displaying reduced activity at lower pH (Hatanaka et al., 2000; Sugawara et al., 2000a; Wang et al., 2000). System A is sensitive to N-methylated amino acids (Johnson and Smith, 1988) such as $\alpha$-(methylamino)isobutyric acid (MeAIB). This non-metabolised amino acid analogue has a specific affinity for the System A transporter (Christensen et al., 1965) and has been used extensively to study this transport system in the placenta (Champion et al., 2004; Jansson et al., 2003; Johnson and Smith, 1988; Mahendran et al., 1993; Moe et al., 1994).

\section{Molecular characterisation and expression in human pla- centa}

Molecular characterisation of system $A$ has revealed there are three highly homologous protein subtypes of this $\mathrm{Na}^{+}$-coupled neutral amino acid transporter known as SNAT1, SNAT2, and SNAT4, which are encoded by three members of the SLC38 gene family ( $S \angle C 38 A 1, S L C 38 A 2$, and SLC38A4respectively) (Hediger et al., 2004; Mackenzie and Erickson, 2004). Expression of $S L C 38 A 1$ has been shown in various tissues including human placenta (Desforges et al., 2006; Wang et al., 2000). SLC38A2is expressed ubiquitously in mammalian tissues (Hatanaka et al., 2000; Sugawara et al., 2000a) and it is therefore assumed that this isoform represents the classical system A amino acid transporter. Functionally, SNAT1 and SNAT2 operate via similar mechanisms (Hatanaka et al., 2000; Wang et al., 2000; Yao et al., 2000). SNAT4 has a lower substrate affinity for neutral amino acids and MeAIB than SNAT1 and SNAT2 $\left(\mathrm{K}_{\mathrm{m}}=6.7 \mathrm{mM}\right.$ verses $0.89 \mathrm{mM}$ and $0.39 \mathrm{mM}$ respectively for MeAIB) (Hatanaka et al., 2001; Sugawara et al., 2000b) and also has a unique ability amongst the other system $A$ isoforms to interact with cationic amino acids in a $\mathrm{Na}^{+}$-independent manner such that it resembles system $y^{+} \mathrm{L}$ (Hatanaka et al., 2001). It was originally thought that $S L C 38 A 4$ ISNAT4 was a liver-specific isoform (Hatanaka et al., 2001). However, we have shown this isoform is present in human placenta (Desforges et al., 2006) and expression has also been confirmed in rat (Novak et al., 2006a) and mouse placenta (Mizuno et al., 2002; Smith et al., 2003).

The high homology between the protein sequences for the 
three system A isoforms has complicated development of SNATspecific antibodies and therefore system A protein expression in placenta and its regulation is poorly understood. Using custom synthesised SNAT isoform-specific antibodies, we have used immunohistochemistry to confirm localisation of each SNAT isoform to the syncytiotrophoblast in both first trimester and term placental samples (Champion etal., 2004; Desforges et al., 2006, 2009). This pattern of localization allows for the possibility that each isoform of system $A$ has the potential to transport amino acids from maternal blood in the intervillous space into the placenta.

\section{System A transport in the placenta}

System A activity in the placenta has been demonstrated in MVM and BM (Dicke et al., 1993; Kudo et al., 1987; Mahendran et al., 1993), however maximal transport capacity per mg protein is much higher in MVM (Hoeltzli and Smith, 1989). Exit of system A substrates across the BM is poorly understood but is thought to occur predominantly via system $\mathrm{L}, \mathrm{a} \mathrm{Na}^{+}$-independent transporter with broad specificity (Jansson, 2001). It is also possible that nonmediated transport across BM may contribute to exit of neutral amino acids from the syncytiotrophoblast (Hoeltzli and Smith, 1989; Kudo and Boyd, 1990).

System A activity in placental cells, tissue, and plasma membrane vesicles has been studied by measuring $\mathrm{Na}^{+}$-dependent uptake of radiolabelled MeAIB, used at tracer concentrations. It is therefore likely that the majority of these studies reflect SNAT2mediated transport as this isoform has the highest affinity for MeAIB (Hatanaka et al., 2000). Localisation of SNAT1, SNAT2, and SNAT4 protein to the syncytiotrophoblast raises the question of the relative functional importance of each isoform for amino acid transport from mother to fetus. The broader substrate specificity of SNAT4 suggests it could mediate the $\mathrm{Na}^{+}$-independent transport of cationic amino acids such as arginine (Hatanaka et al., 2001) as well as the $\mathrm{Na}^{+}$-dependent transport of neutral amino acids typical of system $A$. Our current research aims to determine the functional importance of each SNAT isoform for amino acid transport by system A across the human placenta (Desforges et al., 2008; Desforges et al., 2009). Our experimental approach is to knockdown the individual SNAT isoforms using siRNA technology and examine the effect on $\mathrm{Na}^{+}$-dependent MeAIB transport. We have recently achieved successful knockdown of $S L C 38 A 1$ mRNA in primary cytotrophoblast cells and preliminary experiments show this was associated with reduced MeAIB uptake, suggesting SNAT1 plays an important role by contributing to system A activity in the placenta (Desforges et al., 2008).

\section{Placental system A activity and fetal growth during normal pregnancy}

As pregnancy advances, the fetus grows at a faster rate than the placenta (Sands and Dobbing, 1985; Thomson et al., 1969). Towards the end of pregnancy, human fetal weight increases from $\sim 1 \mathrm{~kg}$ at 27 weeks gestation to $3.5 \mathrm{~kg}$ at term. This is a growth rate of around 30-35g per day (Schneider, 1996) which equates to an amino acid requirement of $40-60 \mathrm{mmol}$ per day (Smith, 1986). It therefore seems reasonable to assume the nutrient transporting capacity of the placenta increases with gestation in order to support accelerated fetal growth. Increased transport of nutrients across the placenta over gestation is likely to be achieved through alterations in placental perfusion, an increase in MVM and BM surface area and changes in transporter abundance or activity in the syncytiotrophoblast. There is also a progressive thinning of the placental exchange barrier towards term which further facilitates nutrient exchange (Jones and Fox, 1991).

Studies using both MVM vesicles and placental villous fragments have shown the activity of the system $A$ amino acid transporter increases between first trimester and term (Mahendran et al., 1994; Desforges et al., 2009). The factors responsible for increased system A activity in the placenta during the course of normal pregnancy are currently unknown. We are exploring the possibility that there is increased expression of SNAT isoform(s) in the placenta at term compared to first trimester, accounting for the increased system $A$ activity. A complex picture is emerging. Placental $S L C 38 A 1$ and $S L C 38 A 2 \mathrm{mRNA}$ expression is comparable between first trimester and term whereas $S L C 38 A 4 \mathrm{mRNA}$ expression is significantly higher in placentas from 6-10 weeks gestation than in term placenta (Desforges et al., 2006). In contrast, protein expression for this subtype of system $A$ is significantly higher at term compared to first trimester (Desforges et al., 2006). Furthermore, our experiments also suggest SNAT4 activity is higher in the placenta during first trimester compared to term (Desforges et al., 2009). These data add to the increasing body of evidence that there are complex gestational changes in placental transporter expression and activity (Atkinson et al., 2006). A change in mRNA expression is not necessarily paralleled by a similar change in protein expression, perhaps attributed to transcriptional regulation, mRNA degradation, translation into protein and post-transcriptional processes. Each of these events and the rate at which they occur may differ between cell types. In the placenta, the relative proportions of syncytiotrophoblast, cytotrophoblast cells and endothelial cells changes over gestation quite markedly. For example, immunohistochemical detection of SNAT4 shows strong staining in fetal blood vessels which are widespread at term but poorly developed in first trimester. Our research into this area is ongoing and we have yet to examine levels of SNAT1 and SNAT2 protein expression in first trimester and term placenta.

\section{Placental system $A$ and fetal growth restriction}

The availability of techniques to sample umbilical cord blood in utero has made it possible to measure plasma amino acid concentrations prior to delivery (Daffos et al., 1985) and studies have shown that these are significantly lower in FGR compared to normal pregnancies (Cetin et al., 1990; Cetin et al., 1988; Cetin et al., 1992). Human in vivo studies with stable isotopes have shown delivery of neutral amino acids to the fetus in normal pregnancy is only just sufficient to meet requirements (Cetin, 2001), and in FGR maternofetal ${ }^{13} \mathrm{C}$-leucine transfer is reduced (Marconi et al., 1999). Such findings provide the rationale for studying placental amino acid transport systems in relation to FGR. Evidence of a defect in placental system A amino acid transport in fetal growth restriction was first obtained by Dicke and Henderson in 1988 (Dicke and Henderson, 1988). In a later study, Mahendran et al.,1993) found that MeAIB uptake by MVM was reduced by $63 \%$ in FGR pregnancies ( $<3^{\text {rd }}$ percentile), and this was predominantly due to a reduction in the $V_{\text {max }}$ of system $A$. The affinity of the transporters $\left(\mathrm{K}_{\mathrm{m}}\right)$ was not altered. This would imply that either the turnover of system $A$ transporters was reduced or the number of 
active carrier proteins in MVM was reduced in FGR. The reduction in MVM system A activity has been shown to be related to the severity of FGR (Glazier et al., 1997) but the molecular mechanisms responsible are unknown. mRNA expression for the three system $A$ isoforms is comparable in placentas from pregnancies complicated by FGR versus normal (Malina et al., 2005) (and M.Desforges, unpublished observations). Levels of SNAT protein expression in the placenta and localization of functional SNAT proteins has yet to be examined in cases of FGR.

The work on the system A amino acid transporter in MVM and BM from placentas of pregnancies affected by FGR has lead to similar studies on other nutrient transporters. As has been reviewed recently (Atkinson et al., 2006; Jansson, 2001) it is now clear that the activity of a range of transporters in MVM and BM is decreased in FGR as compared to normal. It is also apparent that not all transporters are affected (e.g. glucose) and the activities of some transporters, such as PMCA as described above, are actually increased. These data suggest changes in activity of some transporters are part of the cause of FGR, whereas others, such as PMCA, are part of a fetoplacental response to reduced fetal growth.

Evidence from three separate animal studies provides weight to the theory that alterations in the activity of system A may cause, rather than merely be associated with, altered fetal growth. Firstly, inhibition of placental system $A$ activity in pregnant rats, achieved by injecting the mother with high concentrations of MeAIB, is associated with suboptimal fetal growth (Cramer et al., 2002). Secondly, in a rat model of FGR in which dams were fed a protein restricted diet, there was a decrease in placental system A activity that preceded in gestation the decrease in fetal growth (Jansson et al., 2006a). Thirdly, in a mouse model of FGR which displays alterations in placental structure and function that are very similar to those found in human FGR (Sibley et al., 2004), fetal growth restriction, as in the rat model, is preceded by alterations in placental system A activity (Constancia et al., 2002).

This mouse model, achieved by knocking out placental-specific lgf2 (P0), leads to placental growth restriction from embryonic day 12 (E12) but fetal growth restriction only from E19 (Constancia et al., 2002). Therefore at E16 there is a high fetal/ placental weight ratio suggesting increased placental transport efficiency. Indeed, at E16, maternofetal ${ }^{14} \mathrm{C}$-MeAIB transport is increased in the PO knockouts, suggesting that upregulation of system $A$ in these placentas enables maintenance of fetal growth despite reduced placental size. Interestingly, in humans, Godfrey et al.,1998) found that MVM from smaller babies (within the range of normal pregnancies) had increased system A activity (Godfrey et al., 1998). The authors also found an inverse relationship between system $A$ activity and placental size. These observations suggest there is a compensatory upregulation of system A transport in smaller placentas during normal pregnancy in an attempt to maintain sufficient transfer capacity. By E19 in the P0 knockout mice, transport of ${ }^{14} \mathrm{C}$-MeAIB is similar to that observed in wild type mice (Constancia et al., 2002), suggesting that when upregulation of system $A$ is lost, normal fetal growth cannot be sustained. These changes in placental system A activity in P0 knockout mice were specifically associated with changes in S/c38a4 expression (Constancia et al., 2005). Knocking-out placental S/c38a4 in mice is associated with fetal growth restriction (Fowden etal., 2006) suggesting placental SNAT4 is important for the transport of amino acids required to maintain normal fetal growth in this species. We have been interested in the function of this isoform of system A in human placenta; however, our data suggest placental SNAT4 may not be as important in humans at later stages of pregnancy as it appears to be in mice (Desforges et al., 2009).

\section{Placental system A and fetal overgrowth}

Delivery of large-for-gestational age (LGA) or macrosomic (birth weight $>4000 \mathrm{~g}$ ) babies complicates $40 \%$ of pregnancies affected by diabetes (Berk et al., 1989). It represents a risk factor for operative delivery, traumatic birth injury, and developing diabetes and obesity later in life (Pettitt et al., 1993; Zhang et al., 2008). It is thought that these LGA babies result from increased substrate availability during intrauterine development which stimulates fetal insulin secretion and fetal growth (Jansson et al., $2006 b)$. There are different forms of maternal diabetes which include gestational diabetes mellitus (GDM), Type-I and Type-II diabetes and in addition, some of these cases of diabetes will be well controlled which can complicate interpretation of data. In vivo studies have demonstrated that the umbilical delivery of amino acids is significantly increased even in well controlled GDM despite maternal substrate levels being comparable to normal pregnancies (Cetin et al., 2005). This has prompted investigation into placental amino acid transport in diabetic mothers. One study has shown higher system A activity in the MVM of placentas from pregnancies complicated with GDM or Type-I diabetes with or without LGA births compared to normal pregnancy (Jansson et al., 2002a). In contrast, our laboratory has also shown that system A activity is reduced in the MVM of placentas from macrosomic babies born to diabetic mothers (Kuruvilla et al., 1994). The reasons for these disparate observations may be related to differences in study populations and the placental to fetal weight ratios of theses cohorts. In well controlled diabetic women, placental morphology appears to be relatively normal (Mayhew et al., 1994), however when associated with macrosomia, the placentas are often larger (Jansson et al., 2002a; Kuruvilla et al., 1994). It is possible that the reduced placental amino acid transporter activity we observed could be compensated for by the associated increased placental size observed.

Maternal obesity is also associated with fetal overgrowth and an increased risk of pregnancy complications (Galtier et al., 2008; Guelinckx et al., 2008; Robinson et al., 2005). Pre-pregnancy body mass index (BMI, calculated by dividing weight by height ${ }^{2}$ ) correlates with fetal birthweight and placental weight in normal, uncomplicated, term singleton pregnancies without diabetes (Swanson and Bewtra, 2008). The mechanisms underlying fetal overgrowth in obese pregnant women are largely unknown. Obesity is on the increase and therefore maternal obesity and the associated pregnancy complications are becoming a significant clinical problem which is prompting research to investigate whether there is altered placental function in obese mothers (Jansson et al., 2007; Jones et al., 2008).

\section{Regulation of System A by external factors}

Regulation of amino acid transport across the syncytiotrophoblast by system $A$ is likely to be complex involving multiple pathways and differential regulation of the three SNAT isoforms. By analogy with other tissues, this is likely to involve alterations in 
transporter mRNA and protein expression, trafficking of preformed protein to the cell membrane, and changes in transporter activity/turnover. The regulatory factors responsible for altered placental system A activity in cases of FGR and fetal overgrowth are currently under investigation. There is evidence to suggest these regulatory factors could include oxygen tension, substrate levels, as well as some hormones and growth factors (Jones et al., 2007).

Oxygen may regulate system $A$ based on a study using human lung fibroblast cells which demonstrated hypoxia inhibits MeAIB uptake (Berk et al., 2000). System A activity is also reduced in cytotrophoblast cells cultured in low oxygen tensions and this is associated with decreased expression of $S \angle C 38 A 1$ and $S \angle C 38 A 2$ mRNA (Nelson et al., 2003). Altered blood flow to the placenta in pregnancies associated with FGR and preeclampsia, discussed earlier in this chapter, leads to reduced oxygen delivery. It is therefore possible that placental system A activity could be downregulated by reduced oxygen supply in these pregnancy complications. Oxidative stress in the placenta is often associated with FGR and preeclampsia and is thought to result from ischemia-reperfusion injury (Hung et al., 2001). It is therefore interesting that reactive oxygen species have also been shown to reduce MVM system A activity (Khullar et al., 2004).

System $A$ is regulated by substrate availability. Depletion of system A substrates leads to an increase in transporter activity when substrates become available again (Smith and Depper, 1974). This response is known as adaptive regulation and is perhaps the most understood mechanism of system $A$ regulation. In various cell types, substrate regulation of system $A$ is associated with specific changes in the expression and localisation of SLC38A2/SNAT2 (Franchi-Gazzola et al., 2001; Hyde et al., 2001; Ling et al., 2001). In studies using BeWo choriocarcinoma cells, MeAIB transport has been shown to increase following substrate deprivation and this was associated with upregulation of SLC38A2 mRNA (Jones et al., 2006; Novak et al., 2006b). SNAT2 has an amino acid response element in its promoter region, possibly explaining these findings (Palii et al., 2004). BeWo protein expression for SNAT2 was unaffected in substrate deprivation experiments but there was increased localisation of this isoform to the plasma membrane (Jones et al., 2006). This suggests a similar mechanism to that present in other cell types is responsible for adaptive regulation of system $A$ in placenta. Adaptive regulation of system $A$ has also been demonstrated in term human placental villous fragments (Parrott et al., 2007). System A is also trans-inhibited i.e. high intracellular concentrations of it own substrates can lead to reduced activity (Smith and Depper, 1974). The nutritional status of the mother during pregnancy could impact on substrate availability for system A, for example in teenage pregnancies where maternal diet is poor, or in overweight and obese mothers where substrate availability may be increased.

System $A$ is also sensitive to a wide range of hormones (Shotwell et al., 1983) and its activity has been reported to be upregulated in term placental villous fragments following acute incubation with insulin and leptin (Jansson et al., 2003). Acute upregulation of system $A$ by insulin has also been demonstrated in skeletal muscle cells and this was associated with increased localisation of SNAT2 to the plasma membrane (Hyde et al., 2002). Chronic regulation of system A activity by hormones and growth factors is believed to involve upregulation of transporter gene and protein expression since inhibiting these abolishes the response (Su et al., 1998). A number of in vitro studies have reported regulation of system $A$ activity in placenta by insulin-like growth factors (Bloxam etal., 1994; Karl, 1995; Kniss etal., 1994). In the liver, increased system A activity is observed following experimentally induced diabetes or glucagon treatment and this is due to a selective increase in S/c38a2and S/c38a4 expression whereas S/c38a1 is unaffected (Varoqui and Erickson, 2002). These regulatory factors are likely to be relevant in cases of maternal diabetes and obesity as well as in mothers who have a poor diet.

When considering regulation of system A activity it is important to remember the driving forces involved. As discussed earlier in this chapter, amino acid transport into the cell by system $A$ relies upon co-transport with $\mathrm{Na}^{+}$which in turn is dependent upon a relatively low intracellular $\mathrm{Na}^{+}$concentration. Angiotensin II reduces system A activity in placental villous fragments however this is primarily mediated through a negative effect of angiotensin II on $\mathrm{Na}^{+} / \mathrm{K}^{+} /$ATPase activity (Shibata et al., 2006).

\section{Future Work}

Continuing research into characterizing and understanding the cross-talk between placental nutrient supply and fetal growth is required, and also how this is related to maternal nutrition. Problems yet to be resolved include determining the relationship between all the variables which contribute to placental supply capacity. For example, does reduced uterine blood flow in FGR always occur with altered syncytiotrophoblast structure and expression of transport proteins, or can reduced activity of system A occur in isolation? These investigations will help delineate the placental phenotypes in FGR and, with the use of imaging and other non-invasive modalities, help diagnose those women at high risk of the disease, in settings such as the Placenta Clinic described by Kingdom and colleagues (Toal et al., 2008b).

Our review has mainly focused on placental transport at term. However, appropriate regulation of nutrient transport earlier in gestation will be an important determinant of normal fetal development. There has been some research into placental nutrient transport earlier in gestation, which has been reviewed recently (Atkinson et al., 2006), but further investigations are required into the development of placental nutrient transport across gestation and how this is regulated.

The majority of research has focused on how placental supply capacity is affected by FGR, and therefore further investigation is needed into altered placental structure and function associated with fetal overgrowth.

It will also be important to examine how the major risk factors for poor pregnancy outcome such as stress, obesity and teenage maternity affect placental function, with this information also contributing to understanding the pathophysiology of the placenta in pregnancy complications, and in finding solutions to them. The aim is to identify target molecules and strategies for early diagnosis and therapeutic intervention.

\section{Acknowledgements}

We are very grateful to our colleagues, Drs. Jo Glazier, Sue Greenwood and Melissa Westwood for their very helpful comments on the 
manuscript and to Dr. Carolyn Jones for supplying the electron micrograph in Figure 1. Dr. Michelle Desforges is currently supported by a grant from The Wellcome Trust to Prof. Colin Sibley.

\section{References}

AARDEMA, M.W., OOSTERHOF, H., TIMMER, A., VANROOY, I. and AARNOUDSE, J.G. (2001). Uterine artery Doppler flow and uteroplacental vascular pathology in normal pregnancies and pregnancies complicated by pre-eclampsia and small for gestational age fetuses. Placenta 22: 405-411.

AN, B.S., CHOI, K.C., LEE, G.S., LEUNG, P.C. and JEUNG, E.B. (2004). Complex regulation of Calbindin-D(9k) in the mouse placenta and extra-embryonic membrane during mid- and late pregnancy. Mol Cell Endocrino/214: 39-52.

APLIN, J.D. (1991). Implantation, trophoblast differentiation and haemochoria placentation: mechanistic evidence in vivo and in vitro. J Cell Sci99: 681-692.

ATKINSON, D.E., BOYD, R.D.H. and SIBLEY, C.P. (2006). Placental transport. In The Physiology of Reproduction, (ed. NEILL, J. D.). Raven, pp. 2787-2846.

BAI, X., GREENWOOD, S.L., GLAZIER, J.D., BAKER, P.N., SIBLEY, C.P., TAGGART, M.J. and FYFE, G.K. (2005). Localization of TASK and TREK, twopore domain $\mathrm{K}+$ channels, in human cytotrophoblast cells. J Soc Gynecol Investig 12: 77-83.

BAI, X., LACEY, H.A., GREENWOOD, S.L., BAKER, P.N., TURNER, M.A., SIBLEY, C.P. and FYFE, G.K. (2006). TASK channel expression in human placenta and cytotrophoblast cells. J Soc Gynecol Investig 13: 30-39.

BALKOVETZ, D.F., LEIBACH, F.H., MAHESH, V.B., DEVOE, L.D., CRAGOE, E.J., JR. and GANAPATHY, V. (1986). Na+-H+ exchanger of human placental brushborder membrane: identification and characterization. American Journal of Physiology 251: C852-C860.

BATTAGLIA, F.C. (1986). Placental transport and utilization of amino acids and carbohydrates. Fed Proc 45: 2508-2512.

BELKACEMI, L., BEDARD, I., SIMONEAU, L. and LAFOND, J. (2005). Calcium channels, transporters and exchangers in placenta: a review. Cel/ Calcium 37: 1-8.

BELKACEMI, L., GARIEPY, G., MOUNIER, C., SIMONEAU, L. and LAFOND, J. (2004). Calbindin-D9k (CaBP9k) localization and levels of expression in trophoblast cells from human term placenta. J Cell Tissue Res 315: 107-117.

BERK, J.L., HATCH, C.A. and GOLDSTEIN, R.H. (2000). Hypoxia inhibits amino acid uptake in human lung fibroblasts. $J$ Appl Physio/89: 1425-1431.

BERK, M.A., MIMOUNI, F., MIODOVNIK, M., HERTZBERG, V. and VALUCK, J. (1989). Macrosomia in infants of insulin-dependent diabetic mothers. Pediatrics 83: 1029-1034.

BIRDSEY, T.J., BOYD, R.D., SIBLEY, C.P. and GREENWOOD, S.L. (1997). Microvillous membrane potential $(\mathrm{Em})$ in villi from first trimester human placenta: comparison to Em at term. American Journal of Physiology273: R1519R1528.

BIRDSEY, T.J., BOYD, R.D., SIBLEY, C.P. and GREENWOOD, S.L. (1999). Effect of hyposmotic challenge on microvillous membrane potential in isolated human placental villi. American Journal of Physiology 276: R1479-R1488.

BISSONNETTE, J.M., BLACK, J.A., WICKHAM, W.K. and ACOTT, K.M. (1981). Glucose uptake into plasma membrane vesicles from the maternal surface of human placenta. J Membr Bio/58: 75-80.

BLOXAM, D.L., BAX, B.E. and BAX, C.M. (1994). Epidermal growth factor and insulin-like growth factor I differently influence the directional accumulation and transfer of 2-aminoisobutyrate (AIB) by human placental trophoblast in twosided culture. Biochem Biophys Res Commun 199: 922-929.

BOND, H., DILWORTH, M.R., BAKER, B., COWLEY, E., REQUENA JIMENEZ, A., BOYD, R.D., HUSAIN, S.M., WARD, B.S., SIBLEY, C.P. and GLAZIER, J.D. (2008). Increased maternofetal calcium flux in parathyroid hormone-related protein-null mice. J Physio/586: 2015-2025

BORKE, J.L., CARIDE, A., VERMA, A.K., KELLEY, L.K., SMITH, C.H., PENNISTON, J.T. and KUMAR, R. (1989). Calcium pump epitopes in placental trophoblast basal plasma membranes. American Journal of Physiology 257: c341-c346.

BOTSIS, D., VRACHNIS, N. and CHRISTODOULAKOS, G. (2006). Doppler assessment of the intrauterine growth-restricted fetus. Ann N Y Acad Sci1092: 297-303.
BOYD, R.D.H., D'SOUZA, S.W. and SIBLEY, C.P. (1994). Placental Transfer. In Early Fetal Growth and Development, (ed. WARD, R. H. T.SMITH, S. K. and DONNAI, D.). RCOG Press, pp. 211-221.

BROWNBILL, P., BELL, N.J., WOODS, R.J., LOWRY, P.J., PAGE, N.M. and SIBLEY, C.P. (2003). Neurokinin B is a paracrine vasodilator in the human fetal placental circulation. J Clin Endocrinol Metab 88: 2164-2170.

BROWNBILL, P., EDWARDS, D., JONES, C., MAHENDRAN, D., OWEN, D. SIBLEY, C., JOHNSON, R., SWANSON, P. and NELSON, D.M. (1995). Mechanisms of alphafetoprotein transfer in the perfused human placental cotyledon from uncomplicated pregnancy. J Clin Invest 96: 2220-2226.

BROWNBILL, P., MAHENDRAN, D., OWEN, D., SWANSON, P., THORNBURG, K.L., NELSON, D.M. and SIBLEY, C.P. (2000). Denudations as paracellular routes for alphafetoprotein and creatinine across the human syncytiotrophoblast. Am J Physiol Regul Integr Comp Physio/278: R677-R683.

BROWNBILL, P., MCKEEMAN, G.C., BROCKELSBY, J.C., CROCKER, I.P. and SIBLEY, C.P. (2007). Vasoactive and permeability effects of vascular endothelial growth factor-165 in the term in vitro dually perfused human placental lobule. Endocrinology 148: 4734-4744

CAMELO, J.S., JORGE, S.M. and MARTINEZ, F.E. (2004). Amino acid composition of parturient plasma, the intervillous space of the placenta and umbilical vein of term newborn infants. Braz J Med Biol Res 37: 711-717.

CARTER, A.M. and MYATT, L. (1995). Control of placental blood flow: workshop report. Reprod Fertil Dev 7: 1401-1406.

CETIN, I. (2001). Amino acid interconversions in the fetal-placental unit: The animal model and human studies in vivo. Pediatr Res 49: 148-154.

CETIN, I., CORBETTA, C., SERENI, L.P., MARCONI, A.M., BOZZETTI, P., PARDI, G. and BATTAGLIA, F.C. (1990). Umbilical amino acid concentrations in normal and growth-retarded fetuses sampled in utero by cordocentesis. Am J Obstet Gyneco/162: 253-261.

CETIN, I., DE SANTIS, M.S., TARICCO, E., RADAELLI, T., TENG, C., RONZONI, S., SPADA, E., MILANI, S. and PARDI, G. (2005). Maternal and fetal amino acid concentrations in normal pregnancies and in pregnancies with gestational diabetes mellitus. Am J Obstet Gynecol 192: 610-617.

CETIN, I., MARCONI, A.M., BOZZETTI, P., SERENI, L.P., CORBETTA, C., PARDI, G. and BATTAGLIA, F.C. (1988). Umbilical amino acid concentrations in appropriate and small for gestational age infants: a biochemical difference present in utero. Am J Obstet Gynecol 158: 120-126.

CETIN, I., MARCONI, A.M., CORBETTA, C., LANFRANCHI, A., BAGGIANI, A.M. BATTAGLIA, F.C. and PARDI, G. (1992). Fetal amino acids in normal pregnancies and in pregnancies complicated by intrauterine growth retardation. Early Hum Dev 29: 183-186.

CHAMPION, E.E., MANN, S.J., GLAZIER, J.D., JONES, C.J., RAWLINGS, J.M., SIBLEY, C.P. and GREENWOOD, S.L. (2004). System b and System A amino acid transporters in the feline endotheliochorial placenta. Am J Physiol Regul Integr Comp Physio/287: R1369-R1379.

CHIPPERFIELD, A.R., LANGRIDGE-SMITH, J.E. and STEELE, L.W. (1988) Sodium entry into human placental microvillous (maternal) plasma membrane vesicles. Q J Exp Physio/73: 399-411.

CHRISTENSEN, H.N. (1982). Interorgan amino acid nutrition. Physiol Rev 62: 1193-1233.

CHRISTENSEN, H.N. (1990). Role of amino acid transport and countertransport in nutrition and metabolism. Physiol Rev 70: 43-77.

CHRISTENSEN, H.N., OXENDER, D.L., LIANG, M. and VATZ, K.A. (1965). The use of $\mathrm{N}$-methylation to direct route of mediated transport of amino acids. J Biol Chem 240: 3609-3616.

CLARSON, L.H., GLAZIER, J.D., GREENWOOD, S.L., JONES, C.J., SIDES, M.K and SIBLEY, C.P. (1996). Activity and expression of $\mathrm{Na}(+)-\mathrm{K}(+)-A T P a s e$ in human placental cytotrophoblast cells in culture. J Physio/497 (Pt 3): 735-743.

CLARSON, L.H., ROBERTS, V.H., GREENWOOD, S.L. and ELLIOTT, A.C. (2002) ATP-stimulated $\mathrm{Ca}(2+)$-activated $\mathrm{K}(+)$ efflux pathway and differentiation of human placental cytotrophoblast cells. Am J Physiol Regul Integr Comp Physiol 282: R1077-R1085

CLEAL, J.K., BROWNBILL, P., GODFREY, K.M., JACKSON, J.M., JACKSON, A.A., SIBLEY, C.P., HANSON, M.A. and LEWIS, R.M. (2007). Modification of fetal plasma amino acid composition by placental amino acid exchangers in vitro. J Physio/582: 871-82. 
CNOSSEN, J.S., MORRIS, R.K., TER RIET, G., MOL, B.W., VAN DER POST, J.A., COOMARASAMY, A., ZWINDERMAN, A.H., ROBSON, S.C., BINDELS, P.J., KLEIJNEN, J. et al. (2008). Use of uterine artery Doppler ultrasonography to predict pre-eclampsia and intrauterine growth restriction: a systematic review and bivariable meta-analysis. Cmaj 178: 701-11.

COMAR, C.L. (1956). Radiocalcium studies in pregnancy. Ann N Y Acad Sci64: 281-298.

CONSTANCIA, M., ANGIOLINI, E., SANDOVICI, I., SMITH, P., SMITH, R., KELSEY, G., DEAN, W., FERGUSON-SMITH, A., SIBLEY, C., REIK, W. et al. (2005). Adaptation of nutrient supply to fetal demand in the mouse involves interaction between the Igf2 gene and placental transporter systems. Proc Nat/ Acad SCi US A 102: 19219-19224.

CONSTANCIA, M., HEMBERGER, M., HUGHES, J., DEAN, W., FERGUSONSMITH, A., FUNDELE, R., STEWART, F., KELSEY, G., FOWDEN, A., SIBLEY, C. et al. (2002). Placental-specific IGF-II is a major modulator of placental and fetal growth. Nature 417: 945-948.

CRAMER, S., BEVERIDGE, M., KILBERG, M. and NOVAK, D. (2002). Physiological importance of system A-mediated amino acid transport to rat fetal development. Am J Physiol Cell Physio/282: C153-C160.

DAFFOS, F., CAPELLA-PAVLOVSKY, M. and FORESTIER, F. (1985). Fetal blood sampling during pregnancy with use of a needle guided by ultrasound: a study of 606 consecutive cases. Am J Obstet Gyneco/153: 655-660.

DANCIS, J., KAMMERMAN, S., JANSEN, V. and LEVITZ, M. (1983). The effect of ouabain on placental transport of 86Rb. Placenta 4: 351-9.

DESFORGES, M., LACEY, H.A., GLAZIER, J.D., GREENWOOD, S.L., MYNETT, K.J., SPEAKE, P.F. and SIBLEY, C.P. (2006). SNAT4 isoform of system A amino acid transporter is expressed in human placenta. Am J Physiol Cell Physio/290: C305-C312.

DESFORGES, M., MYNETT, K.J., GREENWOOD, S.L., WESTWOOD, M., SIBLEY, C.P. and GLAZIER, J.D. (2007). Evidence that the SNAT4 isoform of system A is functional in human placental microvillous membrane. Pediatr Res 62: 385.

DESFORGES, M., MYNETT, K.J., JONES, R.L., GREENWOOD, S.L., WESTWOOD, M., SIBLEY, C.P., and GLAZIER, J.D. (2009). The SNAT4 isoform of the system A amino acid transporter is functional in human placental microvillous plasma membrane. J Physiol. 587: 61-72.

DICKE, J.M. and HENDERSON, G.I. (1988). Placental amino acid uptake in normal and complicated pregnancies. Am J Med Sci 295: 223-227.

DICKE, J.M., VERGES, D., KELLEY, L.K. and SMITH, C.H. (1993). Glycine uptake by microvillous and basal plasma membrane vesicles from term human placentae. Placenta 14: 85-92.

DOBSON, P.D. and KELL, D.B. (2008). Carrier-mediated cellular uptake of pharmaceutical drugs: an exception or the rule? Nat Rev Drug Discov 7: 205-220.

DOUGHTY, I.M., GLAZIER, J.D., GREENWOOD, S.L., BOYD, R.D. and SIBLEY, C.P. (1996). Mechanisms of maternofetal chloride transfer across the human placenta perfused in vitro. Am J Physio/271: R1701-R1706.

EATON, B.M., LEACH, L. and FIRTH, J.A. (1993). Permeability of the fetal villous microvasculature in the isolated perfused term human placenta. J Physio/463: 141-155.

EATON, B.M. and YUDILEVICH, D.L. (1981). Uptake and asymmetric efflux of amino acids at maternal and fetal sides of placenta. Am J Physio/241: C106C112.

EDWARDS, D., JONES, C.J., SIBLEY, C.P. and NELSON, D.M. (1993). Paracellular permeability pathways in the human placenta: a quantitative and morphological study of maternal-fetal transfer of horseradish peroxidase. Placenta 14:63-73.

FIRTH, J.A., BAUMAN, K.F. and SIBLEY, C.P. (1983). The intercellular junctions of guinea-pig placental capillaries: a possible structural basis for endothelial solute permeability. J Ultrastruct Res 85: 45-57.

FISHER, G.J., KELLEY, L.K. and SMITH, C.H. (1987). ATP-dependent calcium transport across basal plasma membranes of human placental trophoblast. $\mathrm{Am}$ $J$ Physio/252: C38-C46.

FOWDEN, A.L., SIBLEY, C., REIK, W. and CONSTANCIA, M. (2006). Imprinted genes, placental development and fetal growth. Horm Res 65 Suppl 3: 50-58.

FRANCHI-GAZZOLA, R., SALA, R., BUSSOLATI, O., VISIGALLI, R., DALL'ASTA, V., GANAPATHY, V. and GAZZOLA, G.C. (2001). The adaptive regulation of amino acid transport system $A$ is associated to changes in ATA2 expression. FEBS Lett 490: 11-14.
GAITHER, K., QURAISHI, A.N. and ILLSLEY, N.P. (1999). Diabetes alters the expression and activity of the human placental GLUT1 glucose transporter. $J$ Clin Endocrinol Metab 84: 695-701.

GALTIER, F., RAINGEARD, I., RENARD, E., BOULOT, P. and BRINGER, J. (2008). Optimizing the outcome of pregnancy in obese women: from pregestational to long-term management. Diabetes Metab 34: 19-25.

GLAZIER, J.D., ATKINSON, D.E., THORNBURG, K.L., SHARPE, P.T., EDWARDS, D., BOYD, R.D. and SIBLEY, C.P. (1992). Gestational changes in $\mathrm{Ca} 2+$ transport across rat placenta and mRNA for calbindin9K and $\mathrm{Ca}(2+)$-ATPase. Am J Physio/263: R930-R935.

GLAZIER, J.D., CETIN, I., PERUGINO, G., RONZONI, S., GREY, A.M., MAHENDRAN, D., MARCONI, A.M., PARDI, G. and SIBLEY, C.P. (1997). Association between the activity of the system $A$ amino acid transporter in the microvillous plasma membrane of the human placenta and severity of fetal compromise in intrauterine growth restriction. Pediatr Res 42: 514-519.

GODFREY, K.M., MATTHEWS, N., GLAZIER, J., JACKSON, A., WILMAN, C. and SIBLEY, C.P. (1998). Neutral amino acid uptake by the microvillous plasma membrane of the human placenta is inversely related to fetal size at birth in normal pregnancy. J Clin Endocrinol Metab 83: 3320-3326.

GREENWOOD, S.L., BOYD, R.D.H. and SIBLEY, C.P. (1993a). Transtrophoblast and microvillous membrane potential difference in mature intermediate human placental villi. Am J Physio/265: C460-C466.

GREENWOOD, S.L., BROWN, P.D., EDWARDS, D. and SIBLEY, C.P. (1993b) Patch clamp studies of human placental cytotrophoblast cells in culture. Trophoblast Research 7: 53-68.

GREENWOOD, S.L., CLARSON, L.H., SIDES, M.K. and SIBLEY, C.P. (1996). Membrane potential difference and intracellular cation concentrations in human placental trophoblast cells in culture. J Physio/492 (Pt 3): 629-640.

GUELINCKX, I., DEVLIEGER, R., BECKERS, K. and VANSANT, G. (2008). Maternal obesity: pregnancy complications, gestational weight gain and nutrition. Obes Rev 9: 140-150.

HAMILTON, K., TEIN, M., GLAZIER, J., MAWER, E.B., BERRY, J.L., BALMENT, R.J., BOYD, R.D., GARLAND, H.O. and SIBLEY, C.P. (2000). Altered calbindin mRNA expression and calcium regulating hormones in rat diabetic pregnancy. $J$ Endocrino/ 164: 67-76.

HATANAKA, T., HUANG, W., LING, R., PRASAD, P.D., SUGAWARA, M., LEIBACH, F.H. and GANAPATHY, V. (2001). Evidence for the transport of neutral as well as cationic amino acids by ATA3, a novel and liver-specific subtype of amino acid transport system A. Biochim Biophys Acta 1510: 10-17.

HATANAKA, T., HUANG, W., WANG, H., SUGAWARA, M., PRASAD, P.D., LEIBACH, F.H. and GANAPATHY, V. (2000). Primary structure, functional characteristics and tissue expression pattern of human ATA2, a subtype of amino acid transport system A. Biochim Biophys Acta 1467: 1-6.

HEDIGER, M.A., ROMERO, M.F., PENG, J.B., ROLFS, A., TAKANAGA, H. and BRUFORD, E.A. (2004). The ABCs of solute carriers: physiological, pathological and therapeutic implications of human membrane transport proteinsIntroduction. Pflugers Arch 447: 465-468.

HOELTZLI, S.D. and SMITH, C.H. (1989). Alanine transport systems in isolated basal plasma membrane of human placenta. Am J Physio/256: C630-C637.

HUNG, T.H., SKEPPER, J.N. and BURTON, G.J. (2001). In vitro ischemiareperfusion injury in term human placenta as a model for oxidative stress in pathological pregnancies. Am J Patho/159: 1031-1043.

HYDE, R., CHRISTIE, G.R., LITHERLAND, G.J., HAJDUCH, E., TAYLOR, P.M and HUNDAL, H.S. (2001). Subcellular localization and adaptive up-regulation of the system A (SAT2) amino acid transporter in skeletal-muscle cells and adipocytes. Biochem J355: 563-568.

HYDE, R., PEYROLLIER, K. and HUNDAL, H.S. (2002). Insulin promotes the cell surface recruitment of the SAT2/ATA2 system A amino acid transporter from an endosomal compartment in skeletal muscle cells. J Biol Chem 277: 1362813634

JANSSON, N., GREENWOOD, S.L., JOHANSSON, B.R., POWELL, T.L. and JANSSON, T. (2003). Leptin stimulates the activity of the system A amino acid transporter in human placental villous fragments. J Clin Endocrinol Metab 88 1205-1211.

JANSSON, N., PETTERSSON, J., HAAFIZ, A., ERICSSON, A., PALMBERG, I., TRANBERG, M., GANAPATHY, V., POWELL, T.L. and JANSSON, T. (2006a). 
Down-regulation of placental transport of amino acids precedes the development of intrauterine growth restriction in rats fed a low protein diet. JPhysio/576: 935-946.

JANSSON, N., POWELL, T.L., ROSSANDER-HULTHEN, L., WENNERGREN, M., PRASAD, P. and JANSSON, T. (2007). Relationship between maternal dietary intake, hormone levels and placental transport functions in obese women. Pediatr Res 62: 386 .

JANSSON, T. (2001). Amino Acid Transporters in the Human Placenta. Pediatr Res 49: $141-147$.

JANSSON, T., CETIN, I., POWELL, T.L., DESOYE, G., RADAELLI, T., ERICSSON, A. and SIBLEY, C.P. (2006b). Placental transport and metabolism in fetal overgrowth - a workshop report. Placenta 27 Suppl A: S109-S113.

JANSSON, T., EKSTRAND, Y., BJORN, C., WENNERGREN, M. and POWELL, T.L. (2002a). Alterations in the activity of placental amino acid transporters in pregnancies complicated by diabetes. Diabetes 51 : 2214-2219.

JANSSON, T., EKSTRAND, Y., WENNERGREN, M. and POWELL, T.L. (2001). Placental glucose transport in gestational diabetes mellitus. Am J Obstet Gynecol184: 111-116.

JANSSON, T., SCHOLTBACH, V. and POWELL, T.L. (1998). Placental transport of leucine and lysine is reduced in intrauterine growth restriction. Pediatr Res 44: 532-537.

JANSSON, T., WENNERGREN, M. and ILLSLEY, N.P. (1993). Glucose transporter protein expression in human placenta throughout gestation and in intrauterine growth retardation. J Clin Endocrinol Metab 77: 1554-1562.

JANSSON, T., WENNERGREN, M. and POWELL, T.L. (1999). Placental glucose transport and GLUT 1 expression in insulin-dependent diabetes. Am J Obstet Gyneco/180: 163-168.

JANSSON, T., YLVEN, K., WENNERGREN, M. and POWELL, T.L. (2002b). Glucose transport and system A activity in syncytiotrophoblast microvillous and basal plasma membranes in intrauterine growth restriction. Placenta 23: 392399.

JOHANSSON, M., GLAZIER, J.D., SIBLEY, C.P., JANSSON, T. and POWELL, T.L. (2002). Activity and protein expression of the $\mathrm{Na}+/ \mathrm{H}+$ exchanger is reduced in syncytiotrophoblast microvillous plasma membranes isolated from preterm intrauterine growth restriction pregnancies. J Clin Endocrinol Metab 87: 56869564.

JOHANSSON, M., JANSSON, T. and POWELL, T.L. (2000). Na(+)-K(+)-ATPase is distributed to microvillous and basal membrane of the syncytiotrophoblast in human placenta. Am J Physiol Regul Integr Comp Physio/279: R287-R294.

JOHANSSON, M., KARLSSON, L., WENNERGREN, M., JANSSON, T. and POWELL, T.L. (2003). Activity and protein expression of $\mathrm{Na}+\mathrm{K}+\mathrm{ATPase}$ are reduced in microvillous syncytiotrophoblast plasma membranes isolated from pregnancies complicated by intrauterine growth restriction. J Clin Endocrino/ Metab 88: 2831-2837.

JOHNSON, L.W. and SMITH, C.H. (1980). Monosaccharide transport across microvillous membrane of human placenta. Am J Physio/238: C160-C168.

JOHNSON, L.W. and SMITH, C.H. (1985). Glucose transport across the basal plasma membrane of human placental syncytiotrophoblast. Biochim Biophys Acta 815: 44-50.

JOHNSON, L.W. and SMITH, C.H. (1988). Neutral amino acid transport systems of microvillous membrane of human placenta. Am J Physio/254: C773-C780.

JONES, C.J. and FOX, H. (1991). Ultrastructure of the normal human placenta. Electron Microsc Rev 4: 129-78.

JONES, H.N., ASHWORTH, C.J., PAGE, K.R. and MCARDLE, H.J. (2006). Expression and adaptive regulation of amino acid transport system $A$ in a placental cell line under amino acid restriction. Reproduction 131: 951-960.

JONES, H.N., POWELL, T.L. and JANSSON, T. (2007). Regulation of placental nutrient transport-a review. Placenta 28: 763-774.

JONES, H.N., WOOLLETT, L.A., POWELL, T.L. and JANSSON, T. (2008). Development of a mouse model of obesity in pregnancy. Reprod Sci15: 178A-179A.

JOOST, H.G. and THORENS, B. (2001). The extended GLUT-family of sugar/ polyol transport facilitators: nomenclature, sequence characteristics, and potential function of its novel members (review). Mol Membr Biol 18: 247-256.

KARL, P. (1995). Insulin-like growth factor-I stimulates amino acid uptake by the cultured human placental trophoblast. J Cell Physio/ 165: 83-88.
KARSDORP, V.H., VAN VUGT, J.M., VANGEIJN, H.P., KOSTENSE, P.J., ARDUINI D., MONTENEGRO, N. and TODROS, T. (1994). Clinical significance of absent or reversed end diastolic velocity waveforms in umbilical artery. Lancet 344 : 1664-1668.

KAUFMANN, P., SCHRODER, H. and LEICHTWEISS, H.P. (1982). Fluid shift across the placenta: II. Fetomaternal transfer of horseradish peroxidase in the guinea pig. Placenta 3: 339-348.

KELLEY, L.K., SMITH, C.H. and KING, B.F. (1983). Isolation and partial characterization of the basal cell membrane of human placental trophoblast. Biochim Biophys Acta 734: 91-98.

KERTSCHANSKA, S., KOSANKE, G. and KAUFMANN, P. (1994). Is there morphological evidence for the existence of transtrophoblastic channels in the human placental villi? Trophoblast Research 8: 581-596.

KHULLAR, S., GREENWOOD, S.L., MCCORD, N., GLAZIER, J.D. and AYUK, P.T. (2004). Nitric oxide and superoxide impair human placental amino acid uptake and increase $\mathrm{Na}+$ permeability: implications for fetal growth. Free Radic Biol Med36: 271-277.

KINGDOM, J., HUPPERTZ, B., SEAWARD, G. and KAUFMANN, P. (2000). Development of the placental villous tree and its consequences for fetal growth. Eur J Obstet Gynecol Reprod Bio/92: 35-43.

KNISS, D., SHUBERT, P., ZIMMERMAN, P., LANDON, M. and GABBE, S. (1994). Insulinlike growth factors: Their regulation of glucose and amino acid transport in placental trophoblasts isolated from first-trimester chorionic villi. Journal of Reproductive Medicine 39: 249-256.

KOVACS, C.S., LANSKE, B., HUNZELMAN, J.L., GUO, J., KARAPLIS, A.C. and KRONENBERG, H.M. (1996). Parathyroid hormone-related peptide (PTHrP) regulates fetal-placental calcium transport through a receptor distinct from the PTH/PTHrP receptor. Proc Natl Acad Sci U S A 93: 15233-15238.

KUDO, Y. and BOYD, C.A.R. (1990). Characterization of amino acid transport systems in human placental basal membrane vesicles. Biochim Biophys Acta 1021: 169-174.

KUDO, Y. and BOYD, C.A.R. (2002). Human placental amino acid transporter genes: expression and function. Reproduction 124: 593-600.

KUDO, Y., YAMADA, K., FUJIWARA, A. and KAWASAKI, T. (1987). Characterization of amino acid transport systems in human placental brush-border membrane vesicles. Biochim Biophys Acta 904: 309-318.

KURUVILLA, A.G., D'SOUZA, S.W., GLAZIER, J.D., MAHENDRAN, D., MARESH, M.J. and SIBLEY, C.P. (1994). Altered activity of the system A amino acid transporter in microvillous membrane vesicles from placentas of macrosomic babies born to diabetic women. J Clin Invest 94: 689-695.

LEACH, L. and FIRTH, J.A. (1992). Fine structure of the paracellular junctions of terminal villous capillaries in the perfused human placenta. $J$ Cell Tissue Res 268: 447-452.

LING, R., BRIDGES, C.C., SUGAWARA, M., FUJITA, T., LEIBACH, F.H., PRASAD, P.D. and GANAPATHY, V. (2001). Involvement of transporter recruitment as well as gene expression in the substrate-induced adaptive regulation of amino acid transport system A. Biochim Biophys Acta 1512: 15-21.

MACKENZIE, B. and ERICKSON, J.D. (2004). Sodium-coupled neutral amino acid (System N/A) transporters of the SLC38 gene family. Pflugers Arch 447: 784 795.

MACKENZIE, B., SCHAFER, M.K.H., ERIKSON, J.D., HEDIGER, M.A., WEICH, H and VAROQUI, H. (2003). Functional properties and cellular distribution of the System A glutamine transporter SNAT1 support specialized roles in central neurons. J Biol Chem 278: 23720-23730.

MAHENDRAN, D., BYRNE, S., DONNAI, P., D'SOUZA, S.W., GLAZIER, J.D., JONES, C.J.P. and SIBLEY, C.P. (1994). Na+ transport, $\mathrm{H}+$ concentration gradient dissipation, and system $\mathrm{A}$ amino acid transporter activity in purified microvillos plasma membrane isolated from first-trimester human placenta: Comparison with the term microvillous membrane. Am J Obstet Gyneco/171: 1534-1540.

MAHENDRAN, D., DONNAI, P., GLAZIER, J.D., D'SOUZA, S.W., BOYD, R.D.H. and SIBLEY, C.P. (1993). Amino acid (system A) transporter activity in microvillous membrane vesicles from the placentas of appropriate and small for gesational age babies. Pediatr Res 34: 661-665.

MALINA, A., DAFTARY, A., CROMBLEHOLME, W., MARKOVIC, N. and ROBERTS, J.M. (2005). Placental system A transporter mRNA is not different in 
preeclampsia, normal pregnancy, or pregnancies with small-for-gestationalage infants. Hypertens Pregnancy 24: 65-74.

MARCONI, A.M., PAOLINI, C.L., STRAMARE, L., CETIN, I., FENNESSEY, P.V., PARDI, G. and BATTAGLIA, F.C. (1999). Steady state maternal-fetal leucine enrichments in normal and intrauterine growth-restricted pregnancies. Pediatr Res 46: 114-119.

MATHIEU, C.L., BURNETT, S.H., MILLS, S.E., OVERPECK, J.G., BRUNS, D.E. and BRUNS, M.E. (1989). Gestational changes in calbindin-D9k in rat uterus, yolk sac, and placenta: implications for maternal-fetal calcium transport and uterine muscle function. Proc Nat/ Acad Sci U S A 86: 3433-3437.

MAYHEW, T.M., MANWANI, R., OHADIKE, C., WIJESEKARA, J. and BAKER, P.N. (2007). The placenta in pre-eclampsia and intrauterine growth restriction: studies on exchange surface areas, diffusion distances and villous membrane diffusive conductances. Placenta 28: 233-238.

MAYHEW, T.M., OHADIKE, C., BAKER, P.N., CROCKER, I.P., MITCHELL, C. and ONG, S.S. (2003). Stereological Investigation of Placental Morphology in Pregnancies Complicated by Pre-eclampsia with and without Intrauterine Growth Restriction. Placenta 24: 219-226.

MAYHEW, T.M., SORENSEN, F.B., KLEBE, J.G. and JACKSON, M.R. (1994). Growth and maturation of villi in placentae from well-controlled diabetic women. Placenta 15: 57-65.

MCINTOSH, N., RODECK, C.H. and HEATH, M. (1984). Plasma amino acid concentrations of the mid-trimester human fetus. Biol Neonate 45: 218-224.

MICHEL, C.C. and NEAL, C.R. (1999). Openings through endothelial cells associated with increased microvascular permeability. Microcirculation 6: 45-54.

MILLS, T.A., WAREING, M., BUGG, G.J., GREENWOOD, S.L. and BAKER, P.N. (2005). Chorionic plate artery function and Doppler indices in normal pregnancy and intrauterine growth restriction. Eur J Clin Invest 35: 758-764.

MIZUNO, Y., SOTOMARU, Y., KATSUZAWA, Y., KONO, T., MEGURO, M., OSHIMURA, M., KAWAI, J., TOMARU, Y., KIYOSAWA, H., NIKAIDO, I. et al. (2002). Asb4, Ata3, and Dcn are novel imprinted genes identified by highthroughput screening using RIKEN cDNA microarray. Biochem Biophys Res Commun 290: 1499-1505.

MOE, A.J. (1995). Placental amino acid transport. Am JPhysio/268: C1321-C1331.

MOE, A.J., FURESZ, T.C. and SMITH, C.H. (1994). Functional characterization of $\mathrm{L}$-alanine transport in a placental choriocarcinoma cell line (BeWo). Placenta 15: 797-802.

MORRISS, F.H., BOYD, R.D.H. and MAHENDRAN, D. (1994). Placental transport. In The Physiology of Reproduction, vol. 2 (ed. KNOBIL, E. and NEILL, J. D.). Raven Press, pp. 813-861.

MYLONA, P., CLARSON, H., GREENWOOD, S.L. and SIBLEY, C.P. (1998). Expression of the Kir2.1 (inwardly rectifying potassium channel) gene in the human placenta and in cultured cytotrophoblast cells at different stages of differentiation. Mol Hum Reprod 4: 195-200.

NELSON, D.M., CROUCH, E.C., CURRAN, E.M. and FARMER, D.R. (1990). Trophoblast interaction with fibrin matrix. Epithelialization of perivillous fibrin deposits as a mechanism for villous repair in the human placenta. Am J Pathol 136: 855-865.

NELSON, D.M., SMITH, S.D., FURESZ, T.C., SADOVSKY, Y., GANAPATHY, V., PARVIN, C.A. and SMITH, C.H. (2003). Hypoxia reduces expression and function of system A amino acid transporters in cultured term human trophoblasts. Am J Physiol Cell Physio/284: C310-C315.

NOVAK, D., LEHMAN, M., BERNSTEIN, H., BEVERIDGE, M. and CRAMER, S. (2006a). SNAT expression in rat placenta. Placenta 27: 510-516.

NOVAK, D., QUIGGLE, F. and HAAFIZ, A. (2006b). Impact of forskolin and amino acid depletion upon System A activity and SNAT expression in BeWo cells. Biochimie 88: 39-44.

PALII, S.S., CHEN, H. and KILBERG, M.S. (2004). Transcriptional control of the human sodium-coupled neutral amino acid transporter system A gene by amino acid availability is mediated by an intronic element. J Biol Chem 279: 34633471.

PARDI, G., CETIN, I., MARCONI, A.M., LANFRANCHI, A., BOZZETTI, P., FERRAZZI, E., BUSCAGLIA, M. and BATTAGLIA, F.C. (1993). Diagnostic value of blood sampling in fetuses with growth retardation. N Eng/ J Med328: 692-696.

PARROTT, M.S., VON VERSEN-HOEYNCK, F., NESS, R.B., MARKOVIC, N. and
ROBERTS, J.M. (2007). System A amino acid transporter activity in term placenta is substrate specific and inversely related to amino acid concentration. Reprod Sci14: 687-693.

PETTITT, D.J., NELSON, R.G., SAAD, M.F., BENNETT, P.H. and KNOWLER, W.C. (1993). Diabetes and obesity in the offspring of Pima Indian women with diabetes during pregnancy. Diabetes Care 16: 310-314.

PHILIPPS, A.F., HOLZMAN, I.R., TENG, C. and BATTAGLIA, F.C. (1978). Tissue concentrations of free amino acids in term human placentas. Am J Obstet Gyneco/131: 881-887.

PIJNENBORG, R., BLAND, J.M., ROBERTSON, W.B. and BROSENS, I. (1983). Uteroplacental arterial changes related to interstitial trophoblast migration in early human pregnancy. Placenta 4: 397-413.

POWELL, T.L. and ILLSLEY, N.P. (1996). A novel technique for studying cellular function in human placenta: gestational changes in intracellular $\mathrm{pH}$ regulation. Placenta 17: 661-668.

RICE, P.A., ROURKE, J.E. and NESBITT, E.L., JR. (1976). In vitro perfusion studies of the human placenta. IV. Some characteristics of the glucose transport system in the human placenta. Gynecol Invest 7: 213-221.

ROBINSON, H.E., O'CONNELL, C.M., JOSEPH, K.S. and MCLEOD, N.L. (2005). Maternal outcomes in pregnancies complicated by obesity. Obstet Gynecol 106: $1357-1364$

SANDS, J. and DOBBING, J. (1985). Continuing growth and development of the third-trimester human placenta. Placenta 6: 13-22.

SCHNEIDER, H. (1996). Ontogenic changes in the nutritive function of the placenta. Placenta 17: 15-26.

SHENNAN, D.B. and BOYD, C.A. (1987). Ion transport by the placenta: a review of membrane transport systems. Biochim Biophys Acta 906: 437-457.

SHIBATA, E., POWERS, R.W., RAJAKUMAR, A., VON VERSEN-HOYNCK, F., GALLAHER, M.J., LYKINS, D.L., ROBERTS, J.M. and HUBEL, C.A. (2006). Angiotensin II decreases system A amino acid transporter activity in human placental villous fragments through AT1 receptor activation. Am J Physiol Endocrino/ Metab 291: E1009-E1016.

SHOTWELL, M.A., KILBERG, M.S. and OXENDER, D.L. (1983). The regulation of neutral amino acid transport in mammalian cells. Biochim Biophys Acta 737: 267-284.

SIBLEY, C. and BOYD, R.D. (1998). Mechanisms of transfer across the human placenta. In Fetaland Neonatal Physiology, (ed. POLIN, R. A. and FOX, W. W.). WB Saunders, Philadelphia, pp. 77-89.

SIBLEY, C.P. (1994). Review article: mechanisms of ion transfer by the rat placenta: a model for the human placenta? Placenta 15: 675-691.

SIBLEY, C.P., BAUMAN, K.F. and FIRTH, J.A. (1982). Permeability of the foetal capillary endothelium of the guinea-pig placenta to haem proteins of various molecular sizes. J Cell Tissue Res 223: 165-178.

SIBLEY, C.P. and BOYD, R.D. (1988). Control of transfer across the mature placenta. Oxf Rev Reprod Bio/10: 382-435.

SIBLEY, C.P. and BOYD, R.D.H. (2004). Mechanisms of transfer across the human placenta. In FetalandNeonatal Physiology, vol. 1 (ed. POLIN, R. A.FOX, W. W. and ABMAN, S. H.). Saunders, pp.111-122.

SIBLEY, C.P., COAN, P.M., FERGUSON-SMITH, A.C., DEAN, W., HUGHES, J., SMITH, P., REIK, W., BURTON, G.J., FOWDEN, A.L. and CONSTANCIA, M. (2004). Placental-specific insulin-like growth factor 2 (Igf2) regulates the diffusional exchange characteristics of the mouse placenta. Proc Nat/ Acad SciUS A 101: 8204-8208.

SIBLEY, C.P., GLAZIER, J.D., GREENWOOD, S.L., LACEY, H., MYNETT, K., SPEAKE, P., JANSSON, T., JOHANSSON, M. and POWELL, T.L. (2002). Regulation of placental transfer: the $\mathrm{Na}(+) / \mathrm{H}(+)$ exchanger-a review. Placenta 23 Suppl A: S39-S46.

SIDERI, M., DE VIRGILIIS, G., RAINOLDI, R. and REMOTTI, G. (1983). The ultrastructural basis of the nutritinal transfer: evidence of different patterns in the plasma membranes of the multilayered placental barrier. Trophoblast Research 1: 15-26.

SIMAN, C.M., SIBLEY, C.P., JONES, C.J., TURNER, M.A. and GREENWOOD, S.L. (2001). The functional regeneration of syncytiotrophoblast in cultured explants of term placenta. Am J PhysiolRegul Integr Comp Physio/280: R1116R1122.

SMITH, C.H. (1986). Mechanisms and regulation of placental amino acid transport. 
Fed Proc 45: 2443-2445.

SMITH, C.H. and DEPPER, R. (1974). Placental amino acid uptake. II. Tissue preincubation, fluid distribution, and mechanisms of regulation. Pediatr Res 8: 697-703.

SMITH, C.H., MOE, A.J. and GANAPATHY, V. (1992). Nutrient transport pathways across the epithelium of the placenta. Annu Rev Nutr 12: 183-206.

SMITH, N.C., BRUSH, M.G. and LUCKETT, S. (1974). Preparation of human placental villous surface membrane. Nature 252: 302-303.

SMITH, R.J., DEAN, W., KONFORTOVA, G. and KELSEY, G. (2003). Identification of novel imprinted genes in a genome-wide screen for maternal methylation. Genome Res 13: 558-569.

SOLTESZ, G., HARRIS, D., MACKENZIE, I.Z. and AYNSLEY-GREEN, A. (1985) The metabolic and endocrine milieu of the human fetus and mother at 18-21 weeks of gestation. I. Plasma amino acid concentrations. Pediatr Res 19: 9193.

STRID, H., BUCHT, E., JANSSON, T., WENNERGREN, M. and POWELL, T.L. (2003). ATP dependent Ca2+ transport across basal membrane of human syncytiotrophoblast in pregnancies complicated by intrauterine growth restriction or diabetes. Placenta 24: 445-452.

STRID, H., CARE, A., JANSSON, T. and POWELL, T. (2002). Parathyroid hormone-related peptide (38-94) amide stimulates ATP-dependent calcium transport in the Basal plasma membrane of the human syncytiotrophoblast. $J$ Endocrino/175: 517-524.

STRID, H. and POWELL, T.L. (2000). ATP-dependent Ca2+ transport is upregulated during third trimester in human syncytiotrophoblast basal membranes. Pediatr Res 48: 58-63.

STULC, J. (1989). Extracellular transport pathways in the haemochorial placenta. Placenta 10: 113-119.

STULC, J., STULCOVA, B. and SIBLEY, C.P. (1993). Evidence for active maternalfetal transport of $\mathrm{Na}+$ across the placenta of the anaesthetized rat. $J$ Physiol 470: 637-649.

STULC, J., STULCOVA, B., SMID, M. and SACH, I. (1994). Parallel mechanisms of $\mathrm{Ca}++$ transfer across the perfused human placental cotyledon. Am J Obstet Gynecol170: 162-167.

SU, T.Z., WANG, M., SYU, L.J., SALTIEL, A.R. and OXENDER, D.L. (1998). Regulation of system A amino acid transport in 3T3-L1 adipocytes by insulin. $J$ Biol Chem 273: 3173-3179.

SUGAWARA, M., NAKANISHI, T., FEI, Y.-J., HUANG, W., GANAPATHY, M.E., LEIBACH, F.H. and GANAPATHY, V. (2000a). Cloning of an amino acid transporter with functional characteristics and tissue expression pattern identical to that of system A. J Biol Chem 275: 16473-16477.

SUGAWARA, M., NAKANISHI, T., FEI, Y.J., MARTINDALE, R.G., GANAPATHY,
M.E., LEIBACH, F.H. and GANAPATHY, V. (2000b). Structure and function of ATA3, a new subtype of amino acid transport system $A$, primarily expressed in the liver and skeletal muscle. Biochim Biophys Acta 1509: 7-13.

SWANSON, L.D. and BEWTRA, C. (2008). Increase in normal placental weights related to increase in maternal body mass index. JMatern Fetal Neonatal Med 21: $111-113$

TEASDALE, F. and JEAN-JACQUES, G. (1988). Intrauterine growth retardation: Morphometry of microvillous membrane of the human placenta. Placenta 9: 47 55.

THOMSON, A.M., BILLEWICZ, W.Z. and HYTTEN, F.E. (1969). The weight of the placenta in relation to birthweight. J Obstet Gynaecol Br Commonw 76: 865872.

TOAL, M., CHADDHA, V., WINDRIM, R. and KINGDOM, J. (2008a). Ultrasound detection of placental insufficiency in women with elevated second trimester serum alpha-fetoprotein or human chorionic gonadotropin. J Obstet Gynaecol Can 30: 198-206.

TOAL, M., KEATING, S., MACHIN, G., DODD, J., ADAMSON, S.L., WINDRIM, R.C. and KINGDOM, J.C. (2008b). Determinants of adverse perinatal outcome in high-risk women with abnormal uterine artery Doppler images. Am J Obstet Gynecol198: 330 e1-e7.

TOBIAS, J.H. and COOPER, C. (2004). PTH/PTHrP activity and the programming of skeletal development in utero. J Bone Miner Res 19: 177-182.

VAROQUI, H. and ERICKSON, J.D. (2002). Selective up-regulation of system A transporter mRNA in diabetic liver. Biochem Biophys Res Commun 290: 903 908.

WANG, H., HUANG, W., SUGAWARA, M., DEVOE, L.D., LEIBACH, F.H., PRASAD, P.D. and GANAPATHY, V. (2000). Cloning and functional expression of ATA1, a subtype of amino acid transporter A, from human placenta. JBiochem Biophys Res Commun. 273: 1175-1179.

WAREING, M., GREENWOOD, S.L., FYFE, G.K. and BAKER, P.N. (2006). Reactivity of human placental chorionic plate vessels from pregnancies complicated by intrauterine growth restriction (IUGR). Biol Reprod 75: 518-23.

WILLIAMS, J.L.R., FYFE, G.K., SIBLEY, C.P., BAKER, P.N. and GREENWOOD, S.L. (2007). TEA-sensitive $\mathrm{K}+$ channels regulate hCG secretion and production by human villous cytotrophoblast cells in vitro. Pediatr Res 62: 387 .

YAO, D., MACKENZIE, B., MING, H., VAROQUI, H., ZHU, H., HEDIGER, M.A. and ERICKSON, J.D. (2000). A novel system A isoform mediating $\mathrm{Na}+$ /neutral amino acid cotransport. J Biol Chem 275: 22790-22797.

ZHANG, X., DECKER, A., PLATT, R.W. and KRAMER, M.S. (2008). How big is too big? The perinatal consequences of fetal macrosomia. Am J Obstet Gynecol 198: 517 e1-e6. 


\section{Further Related Reading, published previously in the Int. J. Dev. Biol.}

See our recent Special Issue Epigenetics \& Development edited by Saadi Khochbin and Stefan Nonchev at:

http://www.ijdb.ehu.es/web/contents.php?vol=53\&issue=2-3

See Special Issue Pattern Formation edited by Michael K. Richardson and Cheng-Ming Chuong at: http://www.ijdb.ehu.es/web/contents.php?vol=53\&issue=5-6

The influence of the intrauterine environment on human placental development

Graham J. Burton, Eric Jauniaux and D. Stephen Charnock-Jones

Int. J. Dev. Biol. (2010) 54: 303-312 (doi: 10.1387/ijdb.082764gb)

A twist of insight - the role of Twist-family bHLH factors in development

Ralston M. Barnes and Anthony B. Firulli

Int. J. Dev. Biol. (2009) 53: 909-924

Spatiotemporal expression of the selenoprotein $\mathbf{P}$ genein postimplantational mouse embryos

Se-Ra Lee, Jung-Min Yon, In-Jeoung Baek, Mi-Ra Kim, Chun-Gui Park, Beom-Jun Lee, Young-Won Yun and Sang-Yoon Nam

Int. J. Dev. Biol. (2008) 52: 1005-1011

Puzzles of mammalian fertilization - and beyond

J. Michael Bedford

Int. J. Dev. Biol. (2008) 52: 415-426

An activating mutation in the PDGF receptor-beta causes abnormal morphology in the mouse placenta

Camilla Looman, Tong Sun, Yang Yu, Agata Zieba, Aive Ahgren, Ricardo Feinstein, Henrik Forsberg, Carina Hellberg, Carl-Henrik Heldin, Xiao-Qun Zhang, Karin Forsberg-Nilsson, Nelson Khoo, Reinald Fundele and Rainer Heuchel

Int. J. Dev. Biol. (2007) 51: 361-370

A simple in vivo approach to investigate invasive trophoblast cells Juan A. Arroyo, Toshihiro Konno, Darya C. Khalili and Michael J. Soares Int. J. Dev. Biol. (2005) 49: 977-980

A generalized caspase inhibitor disrupts early mammalian development Zahra Zakeri Richard A. Lockshin, Luis-Miguel Criado-Rodríguez and Carlos Martínez-A Int. J. Dev. Biol. (2005) 49: 43-51

Control of reproduction by Polycomb Group complexes in animals and plants Anne-Elisabeth Guitton and Frederic Berger

Int. J. Dev. Biol. (2005) 49: 707-716

Commitment of hematopoietic stem cells in avian and mammalian embryos: an ongoing story

Françoise Dieterlen-Lièvre

Int. J. Dev. Biol. (2005) 49: 125-130

Changes in the placenta and in the rat embryo caused by the demethylating agent 5azacytidine.

M Vlahovic, F Bulic-Jakus, G Juric-Lekic, A Fucic, S Maric and D Serman

Int. J. Dev. Biol. (1999) 43: 843-846

Transgenic mice ubiquitously expressing human placental alkaline phosphatase (PLAP): an additional reporter gene for use in tandem with beta-galactosidase (lacZ).

M J Skynner, D J Drage, W L Dean, S Turner, D J Watt and N D Allen

Int. J. Dev. Biol. (1999) 43: 85-90

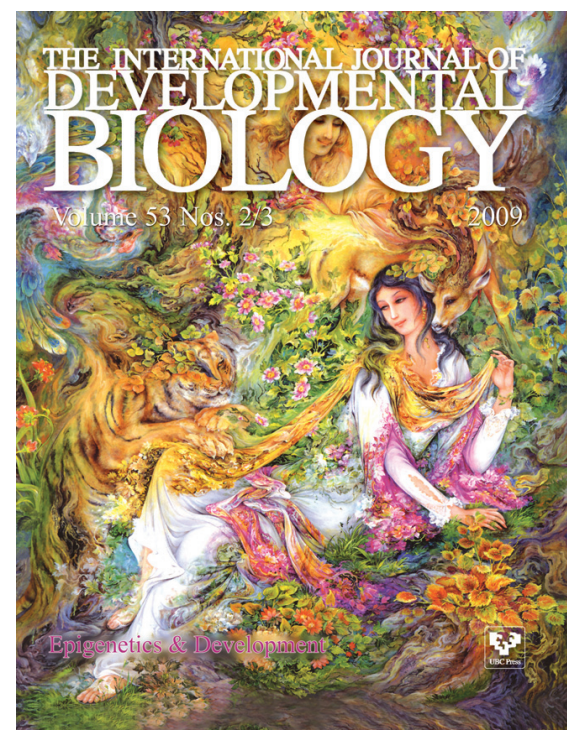

5 yr ISI Impact Factor $(2008)=3.271$

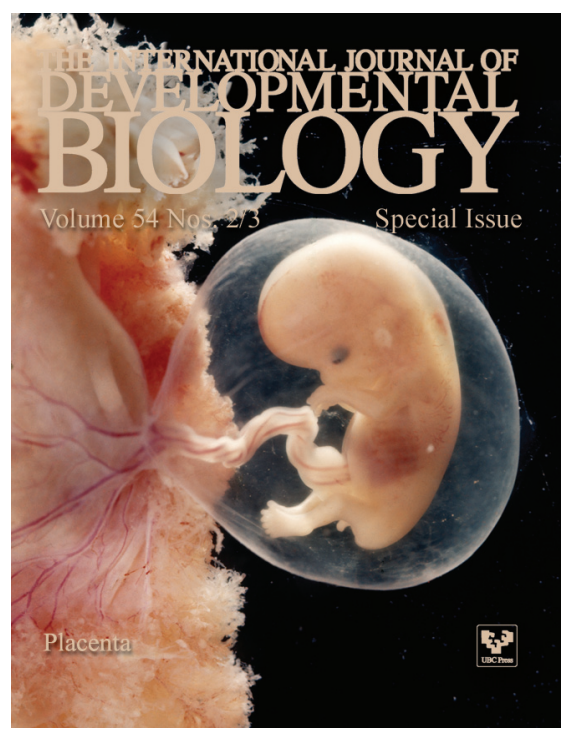

